\title{
When males and females belong to different genera: an interesting case of Synurella/Pontonyx (Crustacea: Amphipoda: Crangonyctidae) co-occurrence
}

\section{Когда самџы и самки принадлежкат к разным родам: интересный случай совместного обитания Synurella/Pontonyx (Crustacea: Amphipoda: Crangonyctidae)}

\author{
Dmitry M. Palatov ${ }^{1}$, Ivan N. Marin ${ }^{2}$ \\ Амитрий М. Пахатов ${ }^{1}$, Иван Н. Марин ${ }^{2}$
}

A.N. Severtsov Institute of Ecology and Evolution of RAS, Moscow 119071, Russia. E-mails: triops@yandex.ru1', coralliodecapoda@mail.ru² Институт экологии и эволюции им. А.Н. Северцова РАН, Москва 119071, Россия.

KEY WORDS: Crustacea, Amphipoda, diversity, Caucasus, Colchis lowland, Black Sea.

КЛЮЧЕВЫЕ СЛОВА: Crustacea, Amphipoda, разнообразие, Кавказ, Колхидская низменность, Черное море.

ABSTRACT. The article describes two interesting cases of co-occurrence of the representatives of different crangonyctid genera (Crustacea: Amphipoda: Crangonyctidae) in the Western Georgia (Caucasus), resembling heterosexual pairs with strong sexual dimorphism. However, using an integrative approach, we describe four new species, by one of the genera Synurella Wrześniowski, 1877 and Pontonyx Palatov et Marin, 2021 from each locality. The discovered species differ genetically and morphologically from the known species from both genera. Despite the presence of a relatively large amount of material, it did not allow us to find individuals of the opposite sex for any of the described species. We believe that a number of such "couples" have already been described from the northern Turkey and other area around Black Sea, where the genus Pontonyx is distributed. Moreover, such an example of the co-occurrence of two crangonyctid genera is described for the first time, previously crangonyctids were found together with other subterranean crustaceans, for example, niphargids (Crustacea: Amphipoda: Niphargidae), but never together with other crangonyctids.

How to cite this paper: Palatov D.M., Marin I.N. 2021. When males and females belong to different genera: an interesting case of Synurella/Pontonyx (Crustacea: Amphipoda: Crangonyctidae) co-occurrence // Arthropoda Selecta. Vol.30. No.4. P.443-472. doi: 10.15298/arthsel.30.4.03

РЕЗЮМЕ. В статье описаны два интересных случая совместного обитания представителей разных родов амфипод-крангониктид (Crustacea: Amphipoda: Crangonyctidae) из Западной Грузии (Кавказ), напоминающих гетеросексуальные пары

The paper is devoted to the memory of Vassily A. Spiridonov. с сильным половым диморфизмом. Однако, используя интегративный подход, мы описываем четыре новых вида, по одному из родов Synurella Wrześniowski, 1877 и Pontonyx Palatov et Marin, 2021 из каждой локации. Обнаруженные виды генетически и морфологически хорошо отличаются от ранее известных видов обоих родов. Несмотря на наличие относительно большого количества материала, он не позволил нам найти особей противоположного пола ни для одного из описанных видов. Мы полагаем, что ряд таких “пар” уже был описан из северной Турции и других районов вокруг Черного моря, где распространен род Pontonyx. Более того, такой пример совместного обитания двух видов крангониктид описан впервые, ранее крангониктиды были найдены вместе с другими стигобионтыми амфиподами, например, нифаргусами (Crustacea: Amphipoda: Niphargidae), но никогда - вместе с другими крангониктидами.

\section{Introduction}

Morphological differences between males and females (sexual dimorphism) among subterranean crustaceans are known for almost all families. This phenomenon is also observed in almost all described genera of the family Crangonyctidae (Crustacea: Amphipoda), usually declared in the larger size in males than in females, larger pereopods I-II (gnathopods) in males have and elongated limbs, for example, uropods (for example, in Volgonyx Marin et Palatov, 2021 [CopilaşCiocianu et al., 2019; Marin, Palatov, 2021a]) and telson (for example, in Bacturus Hay, 1902 [Koenemann, 2000; Copilaş-Ciocianu et al., 2019]); sometimes females are much larger than males, which is also a features of sexual dimorphism. A striking example of sexual dimorphism is described for Synurella odessa- 
na Sidorov et Kovtun, 2015, for which a separate genus Pontonyx is proposed, when males are significantly larger and longer than females [Sidorov, Kovtun, 2015]. The presence of sexual dimorphism in this group is considered common, and rarely males and females are examined separately using molecular genetic methods.

At the same time, during extensive zoological studies in south-western Georgia (Caucasus) in 2009-2019 years, numerous specimens visually belonging to the genus Pontonyx (Crangonyctidae) were sampled in two rather distant localities in Western Georgia: a small pond near Poti $\left(42^{\circ} 11^{\prime} 42.0^{\prime \prime} \mathrm{N} 41^{\circ} 42^{\prime} 19.9^{\prime \prime} \mathrm{E}\right)$ in the Kolkheti area of the Samegrelo-Zemo Svaneti region, and Ispani peat-bog $\left(41^{\circ} 51^{\prime} 41.63^{\prime \prime} \mathrm{N} 41^{\circ} 47^{\prime} 8.94^{\prime \prime} \mathrm{E}\right)$, located in the Kobuleti Natural Reserve in the Adjara region of Western Georgia (see Fig. 1). Numerous stout ovigerous females and rather slender larger males were sampled in both localities. However, the morphological study revealed a distinct sexual dimorphism between the specimens of sexes expressed not only in the shape and in size of the body, but also the structure of the epimeral pleurae, as well as the number of hooks in the retinacules of pleopods. The most surprising results were the barcoding of individuals of both sexes, which showed that they belong to separate genera the females belonged to the genus Synurella Wrześniowski, 1877, while the males surprisingly belonged to the genus Pontonyx. These genera are not closely related and refer to different clades of the family Crangonyctidae [Marin, Palatov, 2021a, b], being separated a long time ago, shortly before the division of North America (Nearctic) and Eurasia (Palaearctic) in the Eocene, about 55-60 Mya [Copilaş-Ciocianu et al., 2019]. Moreover, such an example of the co-occurrence of two crangonyctid genera is described for the first time, previously crangonictids were found together with representatives of other subterranean crustaceans, for example, niphargids (Crustacea: Amphipoda: Niphargidae) [Copilaş-Ciocianu et al., 2014; Copilaş-Ciocianu, Boroş, 2016; Palatov, Chertoprud, 2020], but never together with crangonictids.

We considered it important to describe this case in a separate publication, since, based on the data we obtained, all the species of the "Synurella osellai" species group described earlier (mainly from the northern Turkey) need additional verification and revision in accordance with this study.

\section{Material and methods}

Amphipods were collected using a hand net in various epigean water resources in the Samegrelo-Zemo Svaneti and Adjara regions of the Western Georgia in January 2013 and 2019. Additional sampling was accomplished in Ispani peat bog (lake) (Kobuleti National Park, Adjara region) in AprilOctober 2019. After sampling, crustaceans were fixed in $90 \%$ solution of ethanol. Morphological photographs were made with a digital camera attached to light microscope Olympus ZX10 and Olympus CX21. Photographs of alive coloration of animals in situ were made using digital camera CanonG16. The scanning electron microscopy (SEM) images were made using the Vega3 Tescan microscope in the Yu.A. Orlov Paleontological Museum of the Paleontological Institute of the Russian Academy of Sciences, Moscow. The body length (bl., mm), the dorsal length from the distal margin of head to the posterior margin of telson, without uropod III and both antennas, is used as a standard measurement. The type material is deposited in the collection of Zoological Museum of Moscow State University, Moscow, Russia (ZMMU); additional material is deposited in authors personal collections.

Cytochrome c oxidase subunit I (COI) mtDNA has been proving as extremely informative in previous studies at both population and species level [Avise, 1993; Palatov, Marin, 2020; Marin, Palatov, 2021a, b]. Total genomic DNA was extracted from muscle tissue using the innuPREP DNA Micro Kit (AnalitikJena, Germany). The COI mtDNA gene marker was amplified with the using of the universal primers LCO1490 (5'-GGTCAACAAATCATAAAGATATTGG-3') and HC02198 (5'-TAAACTTCAGGGTGACCAAAAAATCA-3') [Folmer et al., 1994]. Polymerase chain reaction (PCR) were performed on an amplificator T100 (Bio-Rad, USA) under the following conditions: initial denaturation at $96^{\circ} \mathrm{C}$ for $1.5 \mathrm{~min}$ followed by 42 cycles of $95^{\circ} \mathrm{C}$ for $2 \mathrm{~min}$, $49^{\circ} \mathrm{C}$ for 35 seconds, and $72^{\circ} \mathrm{C}$ for $1.5 \mathrm{~min}$. Each chain reaction was concluded by an extension step, set at $72^{\circ} \mathrm{C}$ for $7 \mathrm{~min}$. The volume of $10 \mu \mathrm{L}$ of reaction mixture contained $1 \mu \mathrm{L}$ of total DNA, $2 \mu \mathrm{L}$ of $5 \mathrm{xPCR}$ mix (Dialat, Russia), $1 \mu \mathrm{L}$ of each primer and $5 \mu \mathrm{L}$ of $\mathrm{H}_{2} \mathrm{O}$. The amplification products were separated by using gel electrophoresis of nucleic acids on a $1.5 \%$ agarose gel in $1 \times \mathrm{TBE}$, and then stained and visualized with $0.003 \% \mathrm{EtBr}$ using imaging UV software. PCR products were then sequenced using Genetic Analyzer ABI 3500 (Applied Biosystems, USA) and BigDye 3.1 (Applied Biosystems, USA) with forward and reverse primers. Dataset of aligned sequences of COI mtDNA gene markers, about 617 base pairs in length used in the study were taken from GenBank (NCBI) (Table 1) and author data.

Consensus of complementary sequences was obtained with MEGA 7.0. The best evolutionary substitution model was determined using MEGA 7.0 and jModeltest2.1.141. A phylogenetic analysis was conducted using PhyML 3.0

Table 1. Comparison of pairwise genetic (COI mtDNA) distances ( $p$-distances) (substitutions per 100 nucleotides \pm SE) between the studied species of the genus Pontonyx. Таблица 1. Сравнение попарных генетических (COI mtDNA) дистанций (p-distances) (замен на 100 нуклеотидов $\pm \mathrm{SE})$ между изучаемыми видами рода Pontonyx.

\begin{tabular}{|l|c|c|}
\hline & Pontonyx odessana & Pontonyx colchicus sp.n. \\
\hline Pontonyx colchicus sp.n. & $0.235 \pm 0.0271$ & \\
\hline Pontonyx adjaricus sp.n. & $0.258 \pm 0.0284$ & $0.12 \pm 0.0271$ \\
\hline
\end{tabular}




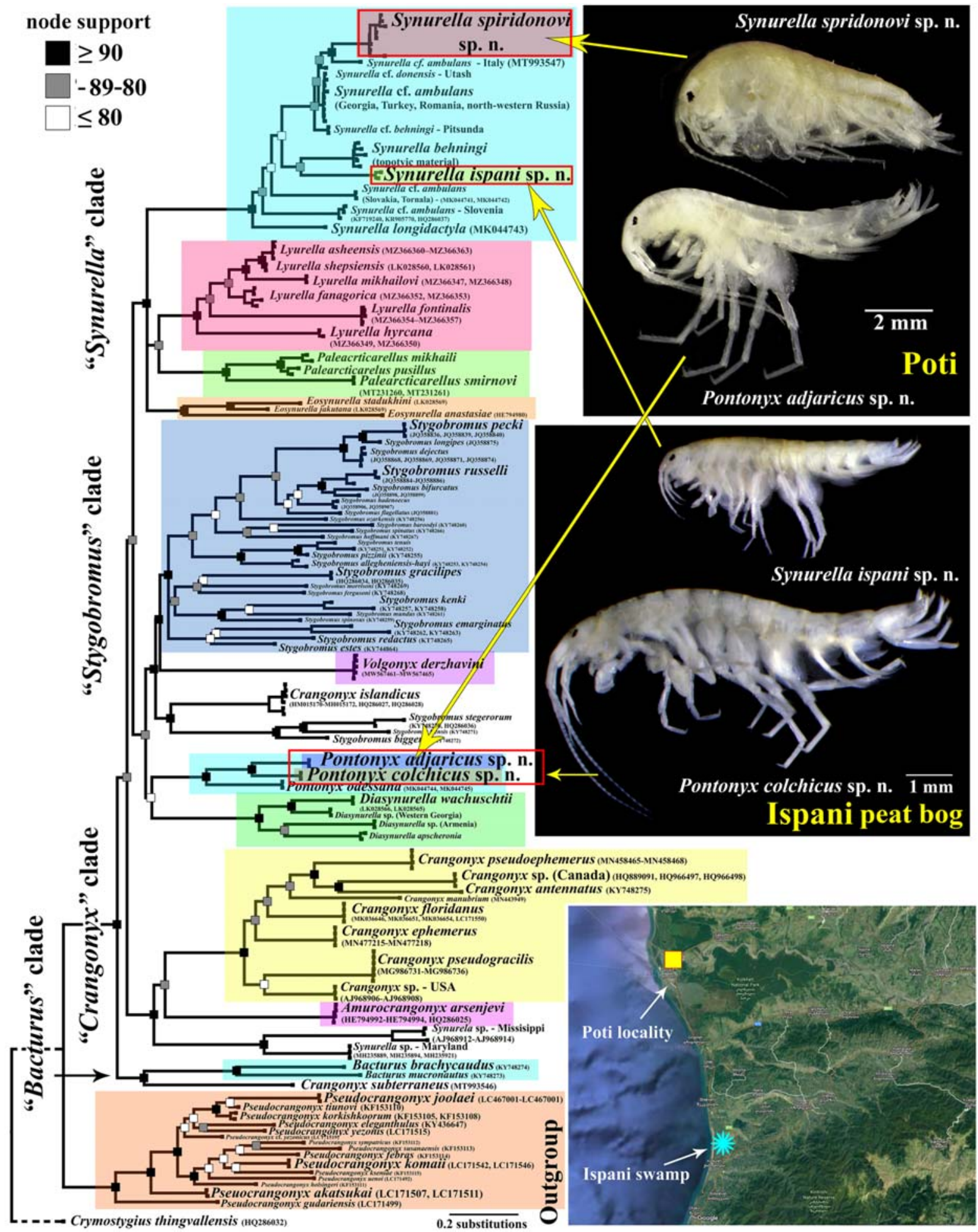

Fig. 1. The phylogenetic reconstruction (tree) of molecular phylogenetic (COI mtDNA gene marker) scenario (GTR+G+I model (Bayesian Information Criterion (BIC)) of the described species from the genera Pontonyx Palatov et Marin, 2021 and Synurella Wrześniowski, 1877 (Crangonyctidae) (additional sequences from GenBank (NCBI). Outgroup include species of the genus Pseudocrangonyx (Pseudocrangonyctidae) and Crymostygius thingvallensis (Crymostygidae). Photographed amphipods after fixation in ethanol.

Рис. 1. Филогенетическая реконструкция (дерево) молекулярно-филогенетического сценария (генный маркер COI мтДНК) (модель GTR+G+I (Бэйсовский информационный критерий (BIC)) описанных видов из родов Pontonyx Palatov et Marin, 2021 и Synurella Wrześniowski, 1877 (Crangonyctidae) (дополнительные последовательности взяты из GenBank (NCBI). Аутгруппа представлена видами рода Pseudocrangonyx (Pseudocrangonyctidae) и Crymostygius thingvallensis (Crymostygidae). Сфотографированные амфиподы после фиксации в этаноле. 


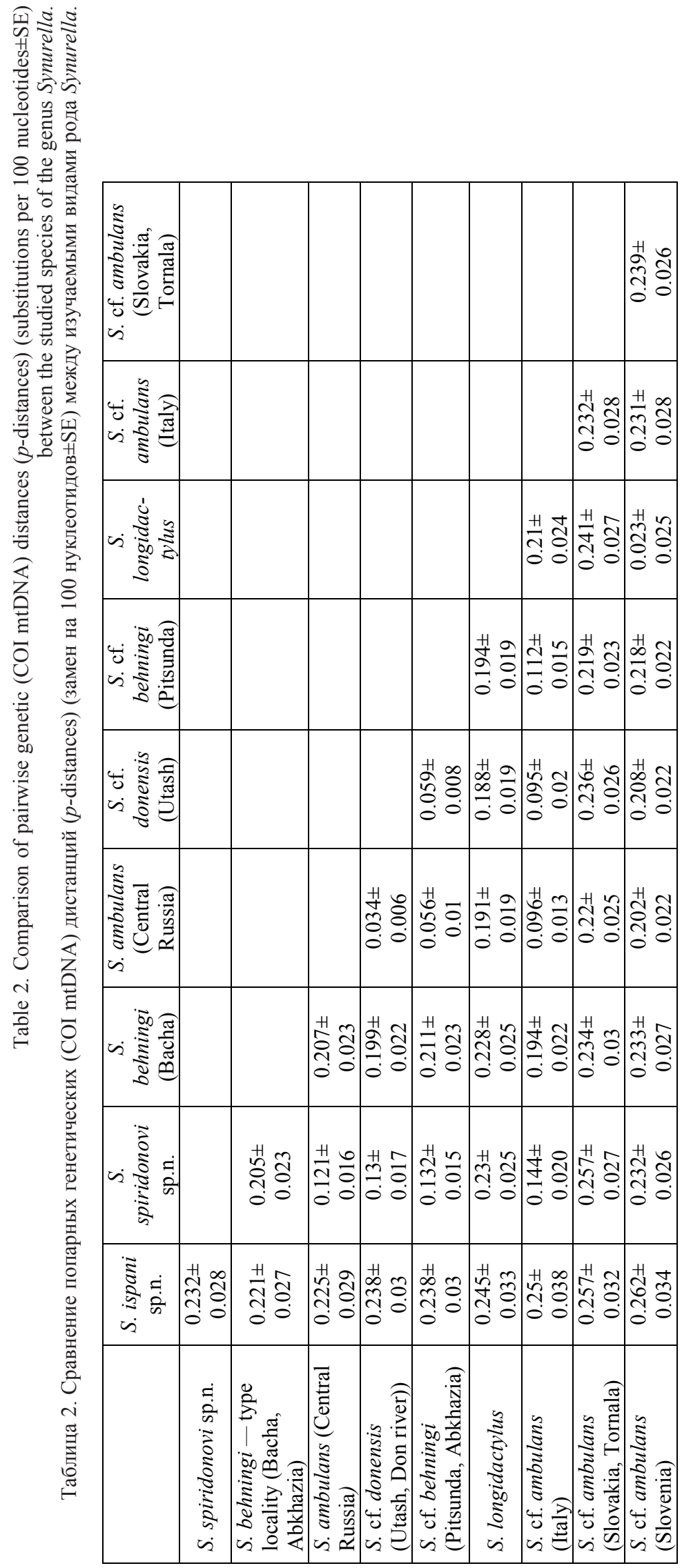

(http://www.atgc-montpellier.fr/phyml/) [Guindon et al., 2010] with several models based on BIC (Bayesian Information Criterion) and AIC (Akaike Information Criterion). The trees with the higher bootstrap probability were used for graphic display of relationships within the family. Bootstrap support is presented for ML analysis. Pairwise genetic divergences ( $p$-distances) was calculated based on COI sequences using MEGA 7.0 with the Kimura 2-Parameter (K2P) model of evolution [Kimura, 1980].

Used abbreviations: $\mathrm{Mx}$ - maxilla; Gn - gnathopod; P - pereopod; Pl pleopod; Ep - epimeral plate; U - uropod.

\section{Results}

\section{PHYLOGENETIC PART}

After a molecular genetic study using COI mtDNA gene marker, the discovered species clearly joined the different and phylogenetically well-distant crangonyctid genera - Pontonyx Palatov et Marin, 2021 $\left(O^{7} \sigma^{7}\right)$ from the "Stygobromus" clade and Synurella Wrześniowski, 1877 (우) from the "Synurella" clade (see Fig. 1). At the same time, all discovered species of both genera were found to be new to science.

The studied (newly discovered together with $P$. odessana) species of the genus Pontonyx form a single clade within the "Stygobromus" clade, well separated from other lineages (genera) of the family Crangonyctidae; the clade is a sister to the genus Diasynurella Behning, 1940. The interspecific genetic divergence between the discovered species of the genus Pontonyx from Western Georgia was about $12 \%$ (see Table 1), showing distinct species-specific genetic divergence, which indicates prolonged isolation and the absence of a gene flow. The $p$-distances from $P$. odessana from Odessa, removed for more than 1000 $\mathrm{km}$ from the localities in Western Georgia, is much larger, being 23-25\% (Table 1).

The interspecific genetic divergence between the discovered species of the genus Synurella from Western Georgia was about 23\% (Table 2), showing distinct species-specific genetic divergence; and $p$-distances of both new species were not less than $10 \%$ from other species of the genus (Table 2). The $p$-distances between the species of the genus Synurella usually exceed $10 \%$, varying from $9.6 \%$ to $26 \%$ (Table 2 ). The lower $p$-distances $( \pm \mathrm{SE})$ were found between $S$. ambulans (Central Russia) and $S$. cf. donensis (Utash) $(0.034 \pm 0.006)$ and $S$. cf. behningi (Pitsunda) $(0.056 \pm 0.01)$, as well as $S$. cf. donensis (Utash) and $S$. cf. behningi (Pitsunda) $(0.059 \pm 0.008)$ (Table 
2). Of course, the taxonomy of the genus Synurella still needs a major revision.

The reconstruction of molecular phylogenetic (COI mtDNA gene marker) scenario (tree) (Fig. 1) support that the "Synurella" clade include 4 crangonyctid genera - Synurella, Eosynurella Martynov, 1931, Lyurella Derzhavin, 1939 and Palearcticarellus Palatov et Marin, 2020 (see Fig. 1; Marin, Palatov [2021]). The genus Pontonyx belongs to the "Stygobromus" clade, being a sister clade to the genus Diasynurella, also known from the south-western (western Georgia, undescribed species) and north-eastern (Dagestan) Caucasus as well as Transcaucasia (Armenia). The genetic divergence between these genera is close to $30 \%$ $(0.307 \pm 0.263$ substitutions per 100 nucleotides $)$, and the estimated time of divergence can be calculated from 5 to 39 Mya, with the average time about 12 Mya (Miocene) (min. and max. after Guy-Haim et al. [2018]; average - 2.5\% $\mathrm{Mya}^{-1}$ for COI mtDNA gene marker after Lefébure et al. [2006], Copilaş-Ciocianu \& Petrusek [2015] for the genus Niphargus (Crustacea: Amphipoda: Niphargidae)). The estimated divergence time between Pontonyx and Diasynurella according to Copilaş-Ciocianu et al. [2019] (1.773\% $\mathrm{Ma}^{-1}$ for COI mtDNA gene marker) is about 17 Mya.

\section{TAXONOMIC PART}

Order Amphipoda Latreille, 1816

Infraorder Gammarida Latreille, 1802

Family Crangonyctidae Bousfield, 1973

Genus Pontonyx Palatov et Marin, 2021

INCLUDED SPECIES. Pontonyx odessana (Sidorov et Kovtun, 2015) (the type species of the genus) and Pontonyx osellai (Ruffo, 1972).

DIFFERENTIAL DIAGNOSIS. The genus Pontonyx is well distinguished from all other Palearctic genera of the family Crangonyctidae by the following features: 1) pigmented body with well-developed pigmented eyes (vs. depigmented Crangonyx, Amurocrangonyx, Diasynurella and Palearcticarellus); 2) completely fused urosomal segments (vs. free urosomal segments in Amurocrangonyx, Crangonyx and Palearcticarellus; urosomal segments 2-3 are partially fused in Diasynurella); 3 ) trapezoidal or subquadrate propodus of pereopod I (vs. oval propodus of pereopod I in Amurocrangonyx, Crangonyx and Palearcticarellus); 4) distoventral palmar angle of propodus of pereopod II with 1-2 strong simple bristles on the inner face (vs. with a row of 3 5 bifurcated bristles in Amurocrangonyx, Crangonyx, Lyurella, Eosynurella, Pontonyx, Palearcticarellus, Synurella and Volgonyx); 5) rudimentary two-segmented uropod III (vs. well-developed two-segmented uropod III in Amurocrangonyx and Crangonyx; and mostly reduced unsegmented in Lyurella); 6) the presence of an additional terminal knob on the peduncle of uropod III (vs. absent in Amurocrangonyx, Crangonyx, Lyurella, Eosynurella, Pontonyx, Palearcticarellus and Synurella); 7) simple endopodite of uropod I (vs. paddle-like endopodite of uropod I in Volgo$n y x) ; 8$ ) with a single additional spine-like setae on dactyli of pereopods III-VII (vs. Amurocrangonyx, Eosynurella and Lyurella); 9) more than 2 coupling hooks in retinacula of pleopods (vs. with more than 2 hooks in Synurella and Diasynurella); 10) well developed inner lobes of labium (vs. almost completely reduced in Eosynurella).

\section{Pontonyx adjaricus Palatov et Marin sp.n.} Figs 1, 2-6.

MATERIAL EXAMINED. Holotype, ơ (bl. $6.0 \mathrm{~mm}$ ), ZMMU Mb-1212, Georgia, Republic of Ajaria (Adjara), Kobuleti, a small stream in the Ispani peat bog, in the western part of the Kobuleti National Reserve, $41^{\circ} 51^{\prime} 41.63^{\prime \prime} \mathrm{N} 41^{\circ} 47^{\prime} 8.94^{\prime \prime} \mathrm{E}$, coll. D. Palatov, 30.01.2013; $5 \mathrm{O}^{7} \mathrm{O}^{7}$, same locality and data as holotype.

ADDITIONAL MATERIAL. $3 \mathrm{O}^{7} \mathrm{O}^{\top}$, Georgia, Republic of Ajaria (Adjara), Kobuleti, Ispani 1 peat bog, $41^{\circ} 51^{\prime} 29^{\prime \prime} \mathrm{N}, 41^{\circ} 47^{\prime} 15^{\prime \prime} \mathrm{E}$, site 1: Sphagnum/mounds, $150 \mathrm{~m} \mathrm{E}$ of NE peat bog edge, sinking (pools/wet Sphagnum btw. mounds), 30.04.2019, coll. A. Przhiboro; $5 O^{7} \sigma^{7}$, same locality, 10.10 .2019 , coll. A. Przhiboro.

ETYMOLOGY. The new species is named after the Republic of Ajaria (Adjara), Georgia, where it was discovered.

DESCRIPTION. Body (Fig. 1): moderately stout; the largest collected $\mathrm{O}^{7}$ has bl. $4.3 \mathrm{~mm}$.

Antenna I (Fig. 2a) about $63 \%$ of body length, about 3.0X longer than antenna II; primary flagellum with 24 segments, with aesthetascs on distal segments; accessory flagellum 2-segmented, distal segment about 3.0X shorter than basal one (Fig. 2d).

Antenna II (Figs $2 c ; 6 f, g$ ): gland clone distinct, distally pointed; peduncle about 1.7-2.0X longer than flagellum, with robust setae tightly covering segments 3 and 4, peduncle of segment 4 about $1.1 \mathrm{X}$ longer than segment 5 ; flagellum 6-segmented; with small calceoli on peduncle and flagellum (Fig. $2 c$ ) or on peduncle only (Fig. $6 f, g$ ).

Mandible (Fig. 3c-f): left mandible (Fig. $3 c, d$ ) incisor 5 -dentate, lacinia mobilis 5 -dentate, with 5 robust plumose accessory setae; molar process with 1 seta. Right mandible (Fig. 3e, f) incisor 4-dentate, lacinia mobilis toothed, triturative, lobes with numerous protuberances; underlying with a row of 5 robust plumose setae; molar process similar to left mandible. Palp 3-segmented, segment 2 with 7 setae; segment 3 about 4.0X longer than wide, with 9-10 separate D-setae, 2 C-setae, 2-3 B-setae and 4 separate E-setae (Fig. 3c,e).

Labrum (upper lip) (Fig. 3a): oval, apical margin with numerous small fine setae.

Labium (lower lip) (Fig. 3b): inner lobes feebly developed.

Maxilla I (Fig. $3 g$ ): inner plate with 5 plumose marginal setae, outer plate with 7 apical comb-spines (Fig. $3 h$ ); palp 2 -segmented, distal segment pubescent, about $3 \mathrm{X}$ of basal segment, apical margin of distal segment with 10 simple setae.

Maxilla II (Fig. 3i): inner and outer plates covered in pubescent setae, subequal in length; outer plate weakly narrowing distally, with 11 apical setae; inner plate narrowing explicitly distally, with group of dense short setae on apex, with oblique row of 3 short plumose setae.

Maxilliped (Fig. $3 k$ ): inner plate much shorter than outer plate, with 5-6 spines and 1-2 simple setae apically, and 12 simple setae laterally; outer plate narrow, with a row of 12-13 medial stiff simple setae of different length; palp quadriarticulate, article 1 without setae on outer margin, article 2 with row of 20-22 simple setae on inner margin and without setae on outer margin, article 3 sub-quadrate; dactylus with 1 seta on outer margin and with 2 thin setae at inner margin, nail long, slender, with 1 thin seta at hinge.

Gnathopod I (Figs 2d;6a): smaller than GnII; coxal plate sub-rectangular, slightly dilated distally, with rounded corners and with 10 apical and numerous facial setae, width/ depth ratio $0.66-0.67$; basis width/length ratio is $0.38 / 1$, with 2 setae on anterior margin, 2 long setae on inner face 


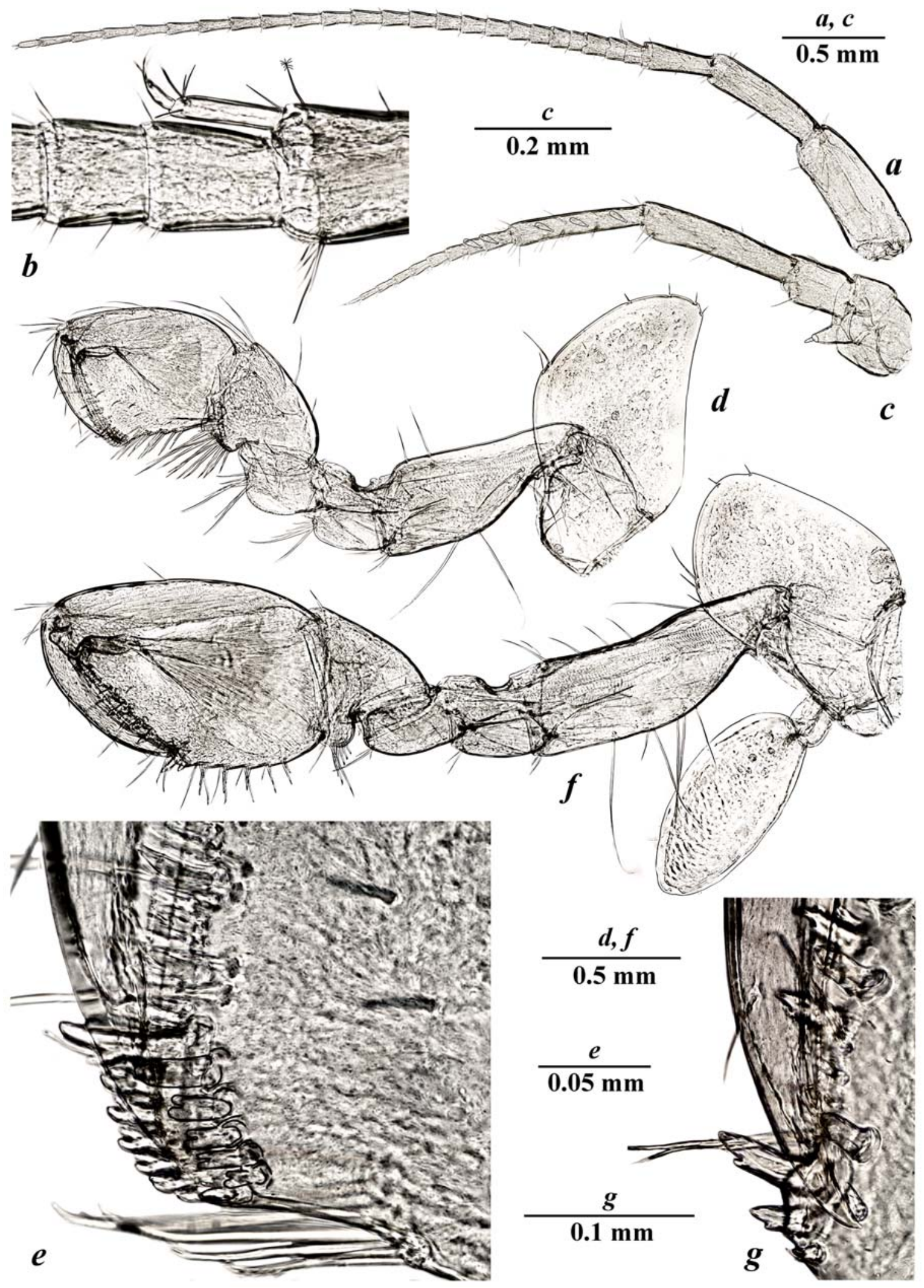

Fig. 2. Pontonyx adjaricus Palatov et Marin sp.n., $\sigma^{7}: a-$ antenna I; $b-$ accessory flagellum of antenna I; $c-$ antenna II; $d-$ gnathopod I; $e$ - distoventral palmar margin of chela of GnII; $f$ - gnathopod II; $g$ - distoventral palmar margin of chela of GnII.

Pис. 2. Pontonyx adjaricus Palatov et Marin sp.n., $\mathrm{O}^{7}: a$ - антенна I; $b-$ добавочный жгутик антенны I; $c$ - антенна II; $d-$ гнатопода I; $e$ - дистовентральный край ладони клешни GnII; $f$ - гнатопода II; $g$ - дистовентральный край ладони клешни GnII. 


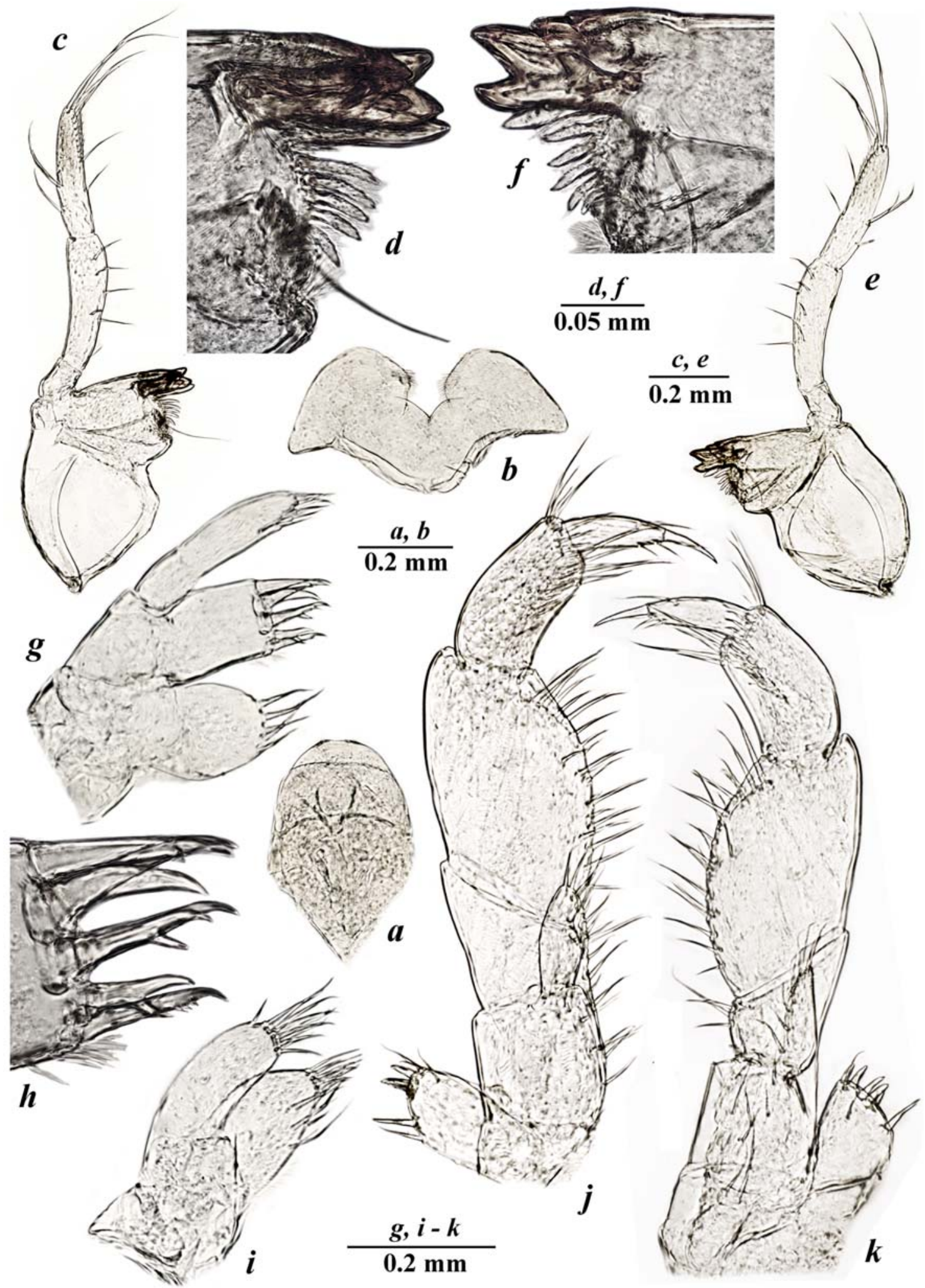

Fig. 3. Pontonyx adjaricus Palatov et Marin sp.n., $o^{7}: a$ - labrum (upper lip); $b$ - labium (lower lip); $c$ - left mandible; $d$ - same, incisor process and pars incisiva; $e$ - right mandible; $f$ - same, incisor process and pars incisiva; $g$ - maxilla I; $h$ - distal margin of inner plate of maxilla I; $i$ - maxilla II; $j, k$ - maxilliped.

Рис. 3. Pontonyx adjaricus Palatov et Marin sp.n., $0^{7}: a-$ лабрум (верхняя губа); $b-$ лабиум (нижняя губа); $c$ - левая мандибула; $d$ - то же, режущий отросток и резцовая часть; $e$ - правая мандибула; $f$ - то же, режущий отросток и резцовая часть; $g$ - максилла I; $h$ - дистальный край внутренней пластины максиллы I; $i$ - максилла II; $j$, $k$ - максиллипед. 


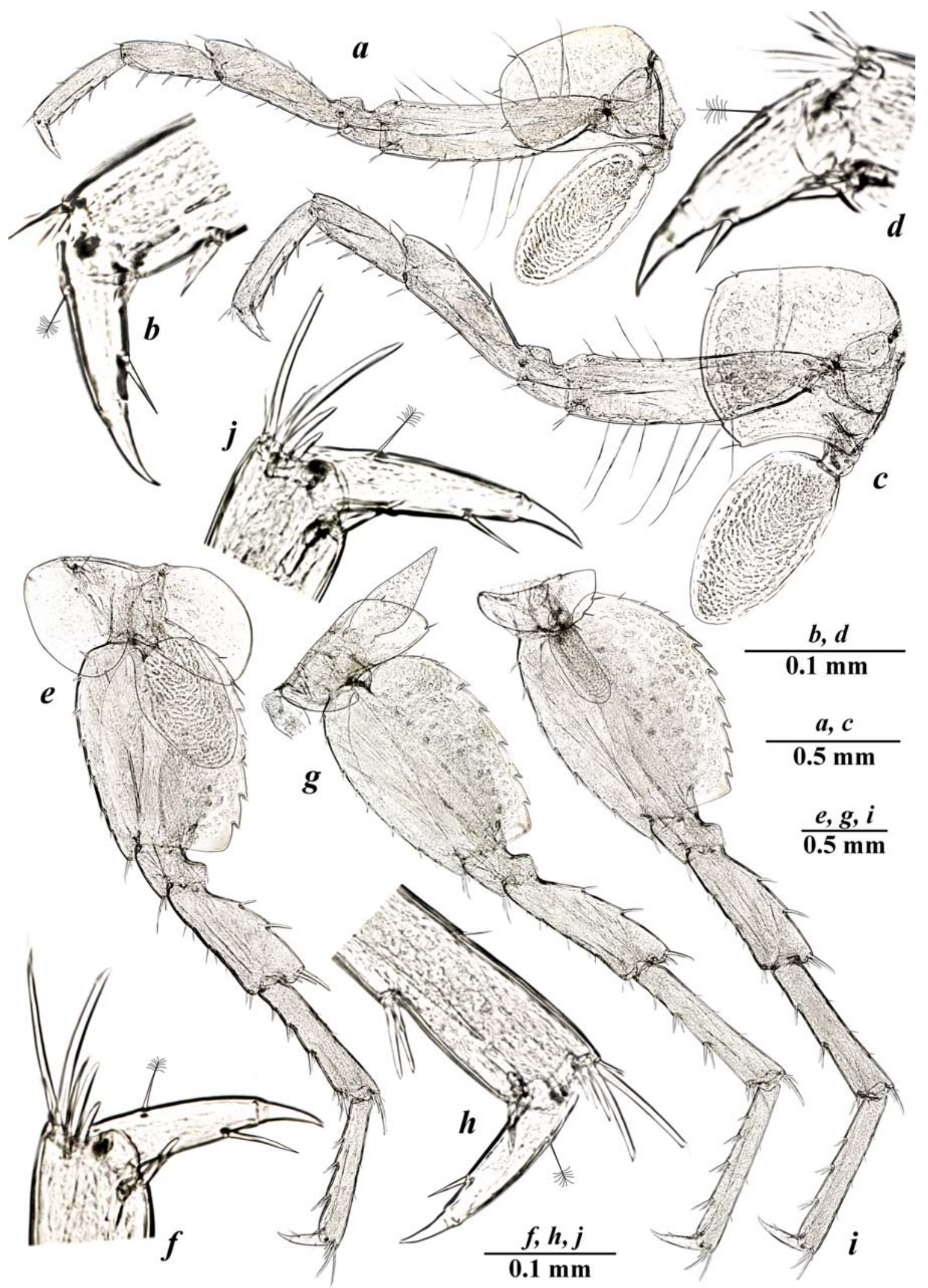

Fig. 4. Pontonyx adjaricus Palatov et Marin sp.n., $\mathrm{O}^{\top}: a$ - pereopod III; $b$ - dactylus of PIII; $c$ - pereopod IV; $d$ - dactylus of PIV; $e$ - pereopod V; $f$ - dactylus of PV; $g$ - pereopod VI; $h$ - dactylus of PVI; $i$ - pereopod VII; $j$ - dactylus of PVII.

Рис. 4. Pontonyx adjaricus Palatov et Marin sp.n., $0^{2}: a$ - переопода III; $b$ - дактилус PIII; $c$ - переопода IV; $d$ - дактилус PIV; $e$ - переопода V; $f$ - дактилус PV; $g$ - переопода VI; $h$ - дактилус PVI; $i$ - переопода VII; $j$ - дактилус PVII. 

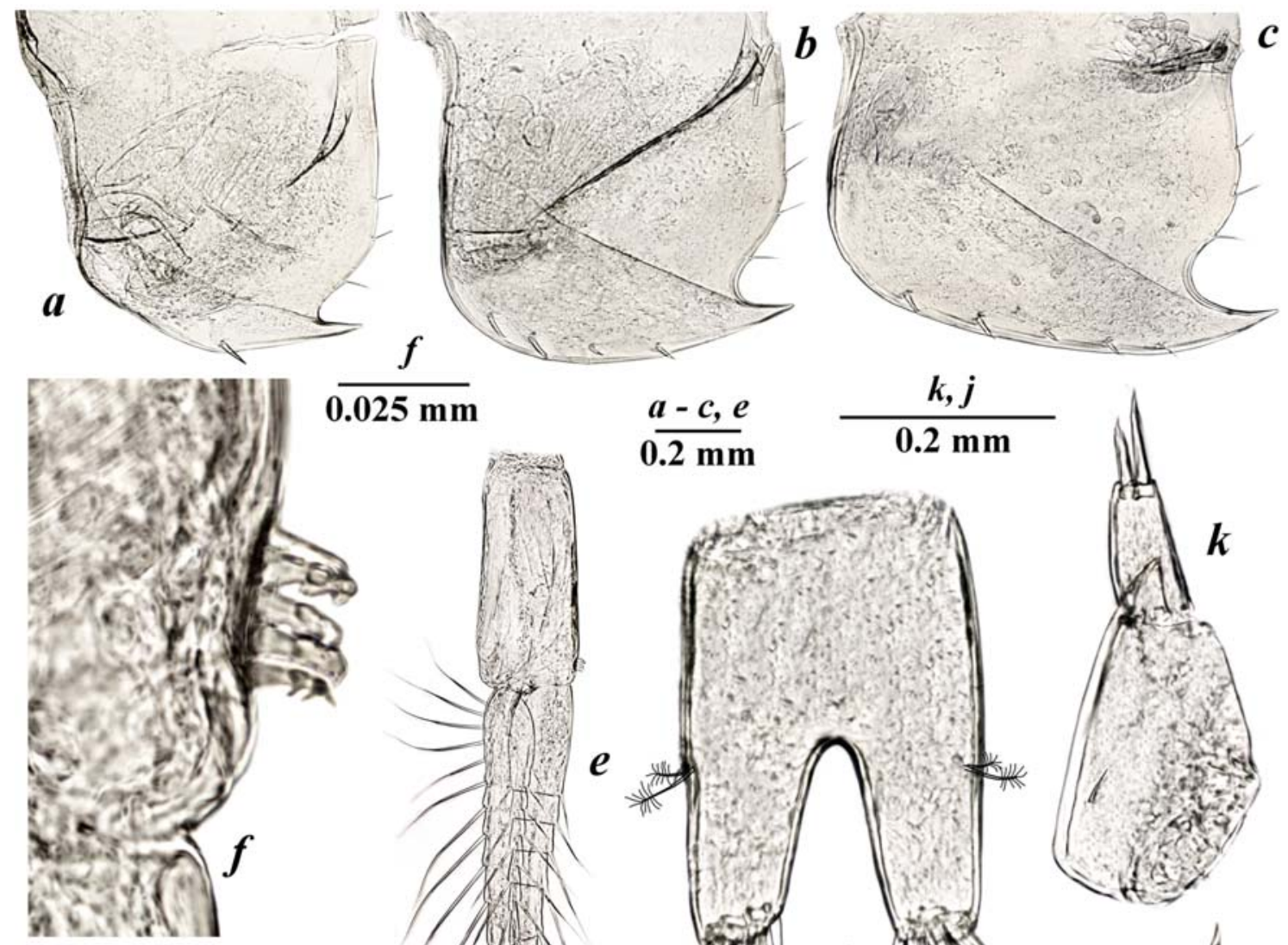

$\overline{0.025 \mathrm{~mm}}$
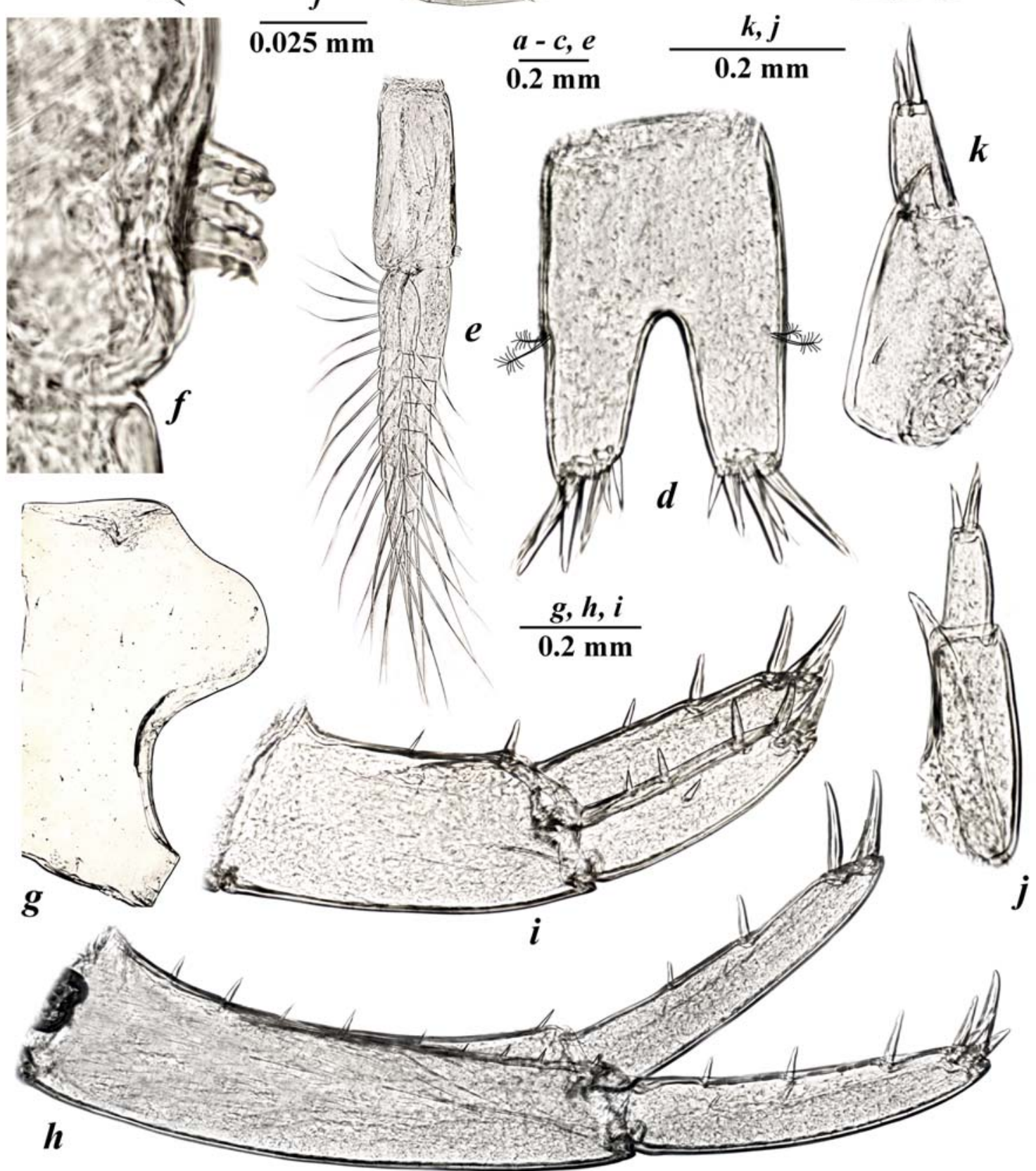

Fig. 5. Pontonyx adjaricus Palatov et Marin sp.n., $O^{7}: a$ - epimeral plate I; $b$ - epimeral plate II; $c$ - epimeral plate III; $d$ - telson; $e$ - pleopod II; $f$ - hooks of retinacula of pleopod II; $g$ - head; $h$ - uropod I; $i$ - uropod II; $j, k$ - uropod III.

Pис. 5. Pontonyx adjaricus Palatov et Marin sp.n., $0^{7}: a-$ эпимеральная пластинка I; $b$ - эпимеральная пластинка II; $c-$ эпимеральная пластинка III; $d$ - тельсон; $e$ - плеопода II; $f$ - крючки ретинакулы плеоподы II; $g$ - голова; $h$ - уропода I; $i$ уропода II; $j, k$ - уропода III. 


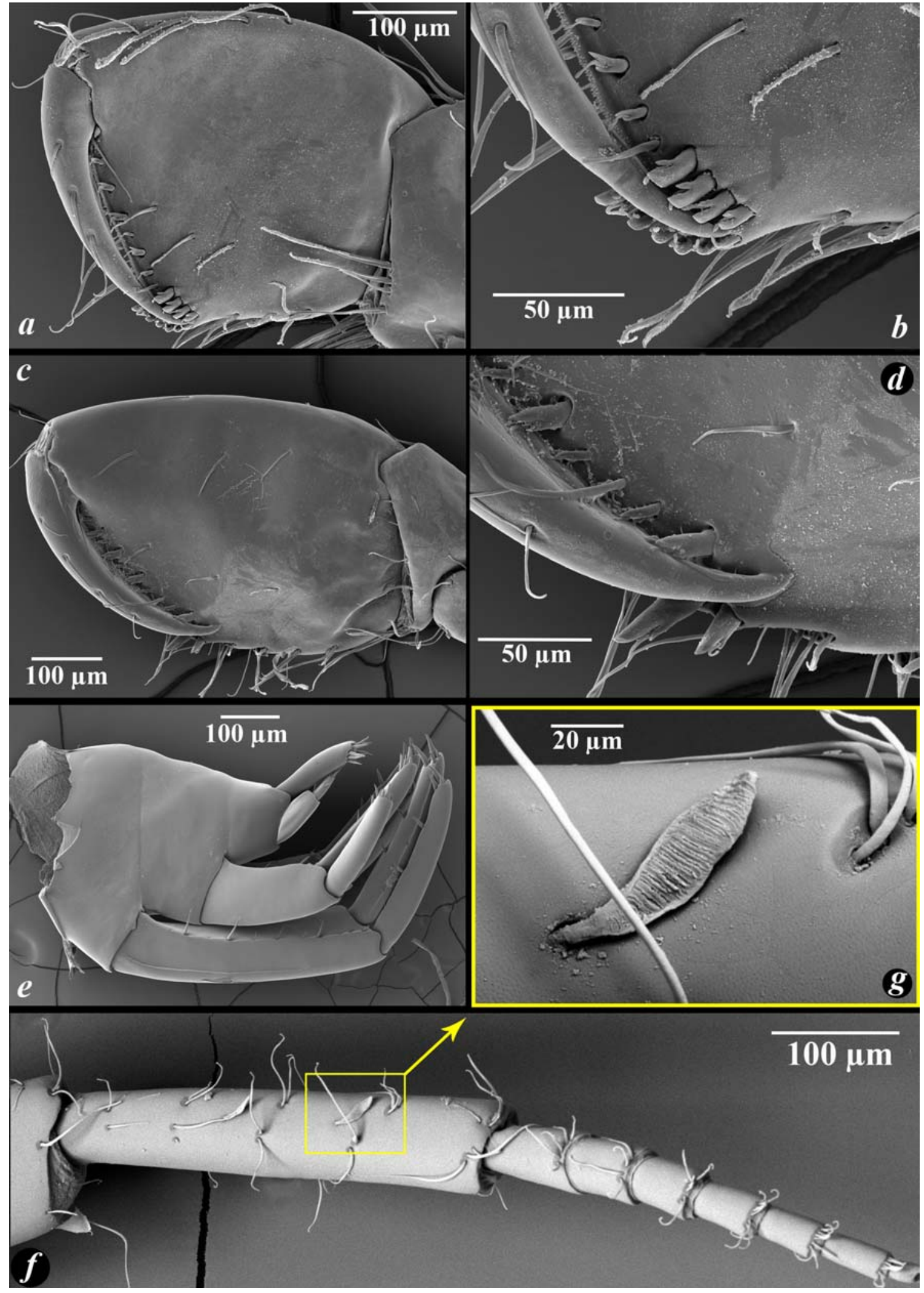

Fig. 6. Pontonyx adjaricus Palatov et Marin sp.n., $\mathrm{O}^{7}: a-$ gnathopod I; $b-$ distoventral palmar margin of chela of GnII; $c-$ gnathopod II; $d$ - distoventral palmar margin of chela of GnII; $e$-urosomal segments, lateral view; $f$ - antenna II; $g$ - calceoli.

Рис. 6. Pontonyx adjaricus Palatov et Marin sp.n., Ơ': $a$ - гнатопода I; $b$ - дистовентральный край ладони клешни GnII; $c-$ гнатопода II; $d$ - дистовентральный край ладони клешни GnII; $e$ - уросомальные сегменты, вид сбоку; $f$ - антенна II; $g$ кальциоли. 
and 5 long setae on posterior margin; merus with 10-11 distal setae; carpus is $0.58 \mathrm{X}$ of basis and $0.72 \mathrm{X}$ of propodus, with 16-18 serrated setae in inner margin and 4 simple setae in outer margin; propodus $1.4 \mathrm{X}$ longer than broad, with 6 simple setae in anterior margin and 3 groups of serrated setae in posterior margin; distal margin of palm (Figs $2 e ; 6 b$ ) almost straight, slightly oblique, with double row of 6 inner and 7 outer bifurcate robust setae; palmar groove (depression) feebly developed, with 4-5 inner and 5-6 outer robust setae; dactylus with 3 outer setae.

Gnathopod II (Figs $2 f ; 6 c$ ): coxal plate sub-rectangular, with 5 apical and numerous facial setae, width/depth ratios is 0.71 ; basis width/length ratio is $0.33 / 1$, with several (5-7) long setae inserted along posterior margin and with 6 medium simple setae in anterior margin; ischium with 2 short simple setae; merus with 2 distal setae; carpus is $0.48 \mathrm{X}$ of length of basis and $0.51 \mathrm{X}$ of propodus, with 1 anterior simple seta and 1 group of plumose posterior setae; propodus $1.5 \mathrm{X}$ longer than broad, with 1 simple anterior seta, 2 superior medial, 3 inferior medial and 5 groups of posterior setae; palm oblique with a double row of 9 inner and 9 outer bifurcate robust setae of different size; palm groove (depression) feebly developed, palmar corner (Figs $2 g ; 6 d$ ) with 2 strong palmar spiniform setae, 1-2 supporting spiniform setae on inner surface; dactylus with 5 setae along anterior margin and few short setae along inner margin.

Pereopod III (Fig. 4a): coxal plate sub-rectangular, with 4 apical and numerous facial setae, width/depth ratio is 0.71 ; basis about $4.1 \mathrm{X}$ as long as wide, with long anterior and posterior simple setae; merus about $0.67 \mathrm{X}$ of basis, about $1.50 \mathrm{X}$ of carpus and about $1.36 \mathrm{X}$ of propodus in length; carpus about $0.90 \mathrm{X}$ of propodus in length; dactylus (Fig. $4 b$ ) about $0.42 \mathrm{X}$ of propodus, with 1 plumose seta on outer margin and 1 additional spine accompanying with seta along ventral margin.

Pereopod IV (Fig. 4c): subequal to PIII in length; coxal plate expanded and broadly convex distally, posterior margin with shallow excavation, distal margin with 4-5 apical short setae and numerous facial setae, width/depth ratio is $0.88 / 1$; basis about $4.1 \mathrm{X}$ as long as wide, with long anterior and posterior simple setae; merus about $0.64 \mathrm{X}$ of basis, about $1.50 \mathrm{X}$ of carpus and about $1.30 \mathrm{X}$ of propodus in length; carpus about $0.86 \mathrm{X}$ of propodus in length; dactylus (Fig. $4 d$ ) about $0.35 \mathrm{X}$ of propodus, with plumose seta on outer margin and 1 additional spine accompanying with seta along ventral margin.

Pereopods V, VI, VII with the length ratio $1 / 1.36 / 1.33$.

Pereopod V (Fig. 4e): coxal plate large, bilobate, with distinct anterior and posterior lobes; posterior and anterior lobes with 1 margin simple seta each, with numerous facial setae; basis about $1.33 \mathrm{X}$ as long as wide, with numerous facial setae, posterior margin slightly convex, armed with 8 shallow serrations, with distinct distal corner, anterior margin with 8 split-tipped robust and 4 distal setae; merus about $0.66 \mathrm{X}$ of basis, $0.93 \mathrm{X}$ of carpus and subequal of propodus in length; dactylus (Fig. 4f) approximately $0.33 \mathrm{X}$ of propodus, with 1 plumose seta on outer margin and 1 additional spine accompanying with seta along ventral margin.

Pereopod VI (Fig. 4g): coxal plate bilobate, with distinct posterior and vestigial anterior lobes; anterior lobe without setae, posterior lobe with 1 margin seta, each with numerous facial setae; basis about $1.50 \mathrm{X}$ as long as wide, with numerous facial setae, posterior margin convex, armed with 8 shallow serrations, anterior margin with 8 split-tipped robust and 3 distal setae; merus about $0.78 \mathrm{X}$ of basis, $0.96 \mathrm{X}$ of carpus and subequal of propodus in length; dactylus (Fig. $4 h$ ) approximately $0.32 \mathrm{X}$ of propodus, with 1 plumose seta on outer margin and 1 additional spine accompanying with seta along ventral margin.

Pereopod VII (Fig. 4i): coxal plate small, semi-lunar, with 3 posterior setae; basis about $1.36 \mathrm{X}$ as long as wide, with numerous facial setae, posterior margin convex, armed with 10 serrated setae, with distinct distal corner; anterior margin with 7 split-tipped robust and 3 distal setae; merus about $0.66 \mathrm{X}$ of basis, about $0.95 \mathrm{X}$ of carpus and about $0.93 \mathrm{X}$ of propodus in length; dactylus (Fig. $4 j$ ) approximately $0.36 \mathrm{X}$ of propodus in length, with 1 plumose seta on outer margin and 1 additional spine accompanying with seta along ventral margin.

Gills, brood plates (Fig. 4): coxal gills on somites IIVII, somites V-VII with lanceolate sternal gill on each. Coxal gills of PII-PVII ovoid, gills/bases pereopod ratios are $0.75 / 1,0.76 / 1,0.72 / 1,0.70 / 1,0.45 / 1$ and $0.38 / 1$, respectively.

Pleopods (Fig. 5e): pleopod I peduncle with 4 coupling hooks in retinacula, without lateral setae; outer and inner rami with 10 and 12 segments, respectively; basal segment of outer ramus with 2 clothes-pin setae. Pleopod II peduncle with 6 coupling hooks in retinacula, without setae; outer and inner rami with 11 and 13 segments, respectively; basal segment of outer ramus with 2 clothes-pin setae. Pleopod III peduncle with 5 coupling hooks in retinacula (Fig. 5f), without lateral setae; outer and inner rami with 8 and 9 segments, respectively; basal segment of outer ramus with 2 clothespin setae.

Epimera. Epimeron I (Fig. 5a) distally produced and sharply pointed, ventral margin with 1 spine, posterior margin convex, with 3 setae. Epimeron II (Fig. 5b) distally produced and sharply pointed, ventral margin armed with 4 spines, posterior margin convex, with 4 setae. Epimeron III (Fig. $5 c$ ) distally produced and sharply pointed, ventral margin armed with 5 spines, posterior margin convex, with 3 setae.

Urosomites completely fused, smooth (Fig. 6e).

Uropod I (Fig. $5 h$ ): peduncle about $4.3 \mathrm{X}$ as long as wide, with dorsointernal row of 7-9 thin short spines 1 subdistal short spine and 1 dorsoexternal thin short spine; exopodite subequal of endopodite in length; endopodite not paddle-like, with 2 dorsolateral and 5 apical spines; exopodite with 3 dorsolateral and 5 apical spines.

Uropod II (Fig. 5i): peduncle about $2.0 \mathrm{X}$ as long as wide, subequal of endopodite in length, with 2 outer short spines; exopodite about $0.9 \mathrm{X}$ of endopodite in length, with 3 outer and 5 apical robust spines; endopodite with 2 outer and 5 apical robust spines.

Uropod III (Fig. 5j, $k$ ): uniramous, peduncle cone-shaped, about $1.8 \mathrm{X}$ as long as wide, with a terminal "pointed knob" and 1 simple seta on lateral margin; apical margin of ramus armed with 3 spines.

Telson (Fig. $5 d$ ): not tapered distally, elongate, $0.63 \mathrm{X}$ as long as broad, as long as uropod III; apical margin cleft about $1 / 2$ of total length; with mix of 7 short and long spines and with 2 additional submarginal plumose setae on each lobe.

COLORATION. The body and appendages yellowish or grayish transparent; well-pigmented black eyes well seen.

GENBANK ACCESSION NUMBERS. MZ449250, MZ449251.

TAXONOMIC REMARKS. The new species can be clearly separated from $P$. odessana (after Sidorov \& Kovtun 
[2015]) in the following features: 1) well-developed, large eyes and a distinctly pigmented body (vs. small, rudimentary eyes and a depigmented body in P. odessana); 2) posteroventral corners of EpI-III with sharp and large spines (vs. posteroventral corners of EpI-III with small and short spines in $P$. odessana); 3 ) inner plate of MxII with oblique row of 3 short plumose setae (vs. inner plate of MxII with oblique row of 5 plumose setae in $P$. odessana); 4) relatively short AI with 24 segments, which are about $60 \%$ of the total body length (vs. AI with 32 segments being about $90 \%$ of total body length in $P$. odessana).

The new species can be clearly separated from $P$. osellai (after Ruffo [1972]) by: 1) smaller body size (the largest collected $O^{7}$ has bl. $4.3 \mathrm{~mm}$ ) (vs. the largest $\sigma^{7}$ has bl. 10.5 $\mathrm{mm}$ in P. osellai);2) left and right mandibles with rows of 5 robust plumose accessory setae (vs. left and right mandibles with a row of 8 robust plumose accessory setae in P. osellai); 3 ) segment 3 of mandibular palp with 9-10 separate Dsetae, 2 C-setae and 2-3 B-setae (vs. 12-13 separate Dsetae, $4 \mathrm{C}$-setae and 5 B-setae in P. osellai); 4) 6 medium simple setae along the anterior margin of basis of PII (vs. with 10-11 long simple setae in P. osellai).

For the differences from Pontonyx colchicus Marin et Palatov sp.n. see below.

DISTRIBUTION AND ECOLOGY. The species is presently known only from the Ispani peat bog $\left(41^{\circ} 51^{\prime} 41.63^{\prime \prime} \mathrm{N}\right.$ $41^{\circ} 47^{\prime} 8.94^{\prime \prime} \mathrm{E}$ ), the Kobuleti Nature Reserve, Kobuleti, Republic of Ajaria (Adjara), Georgia.

\section{Pontonyx colchicus Marin et Palatov sp.n. Figs $1,7-10$.}

MATERIAL EXAMINED. Holotype, ơ (bl. $8.0 \mathrm{~mm}$ ), ZMMU Mb-1213, Georgia, Samegrelo-Zemo Svaneti, Khobi Municipality, small pond near road Chaladidi-Kulevi-Poti, $42^{\circ} 11^{\prime} 42.0^{\prime \prime} \mathrm{N} 41^{\circ} 42^{\prime}$ $19.9^{\prime \prime} \mathrm{E}$, about $2 \mathrm{~m}$ above sea level, hand net sampling, coll. I. Marin, V. Maslova, 29.01.2019.

ADDITIONAL MATERIAL. $3 \mathrm{O}^{7} \mathrm{O}^{7}$, same locality and data as holotype.

ETYMOLOGY. The new species is named after the Kolkhida coastal lowland of the Eastern Black Sea (Colchis), where the new species was discovered.

DESCRIPTION. Body (Fig. 1): moderately stout; the largest collected $\sigma^{7}$ has bl. $8.0 \mathrm{~mm}$.

Antenna I (Fig. 7a) about $56 \%$ of body length, about $2.1 \mathrm{X}$ longer than antenna II; primary flagellum with 24 segments, with aesthetascs on distal segments; accessory flagellum 2-segmented, distal segment about 2.0X shorter than basal one (Fig. $7 b$ )

Antenna II (Fig. 7c): gland clone distinct, distally pointed; peduncle about $2.2 \mathrm{X}$ longer than flagellum, with robust setae tightly covering segments 3 and 4 , peduncle of segment 4 about 1.1X longer than segment 5; flagellum 9segmented; with small calceoli on peduncle and flagellum.

Mandible (Fig. 8c-f): left mandible (Fig. 8c, $d$ ) incisor 5-dentate, lacinia mobilis 5-dentate, with 6 robust plumose accessory setae; molar process with 1 seta. Right mandible (Fig. $8 e, f$ ) incisor 4-dentate, lacinia mobilis toothed, bifurcated, lobes with numerous protuberances; underlying with a row of 4 robust plumose setae; molar process similar to left mandible. Palp 3-segmented, segment 2 with 6 setae; segment 3 about 3.0X longer than wide, with $10-11$ separate $\mathrm{D}$ setae, $1 \mathrm{C}$-seta, 3 B-setae and 4 separate E-setae (Fig. 8c,e)

Labrum (upper lip) (Fig. 8a): oval, apical margin with numerous small fine setae.
Labium (lower lip) (Fig. 8b): inner lobes feebly developed.

Maxilla I (Fig. $8 g$ ): inner plate with 4 plumose marginal setae, outer plate with 7 apical comb-spines (Fig. 8h); palp 2 -segmented, distal segment pubescent, about 3.0X of basal segment, apical margin of distal segment with 8 simple setae.

Maxilla II (Fig. 8i): inner and outer plates covered in pubescent setae, subequal in length; outer plate weakly narrowing distally, with 13 apical setae; inner plate narrowing explicitly distally, with group of dense short setae on apex, with oblique row of 3 short plumose setae.

Maxilliped (Fig. 8j, $k$ ): inner plate much shorter than outer plate, with 5 spines and 1 strong simple seta apically, and 1-2 simple setae laterally; outer plate narrow, with a row of 12 medial stiff simple setae of different length; palp quadriarticulate, article 1 without setae on outer margin, article 2 with a row of 20 simple setae on inner margin and without setae on outer margin, article 3 sub-quadrate; dactylus with 1 seta on outer margin and with 1 thin seta at inner margin, nail long, slender, with 1 thin seta at hinge.

Gnathopod I (Fig. 7d): smaller than gnathopod II; coxal plate sub-rectangular, with rounded corners and with 7 apical and numerous facial setae, width/depth ratios is 0.69 0.70 ; basis width/length ratio is $0.42 / 1$, with 3 short setae on anterior margin, 2 long setae on inner face and 9 long setae on posterior margin; merus with $9-10$ distal setae; carpus is 0.62 of length of basis and 0.80 of length of propodus, with 14-16 serrated setae in inner margin and 3 simple setae in outer margin; propodus $1.35 \mathrm{X}$ longer than broad, with 7 simple setae in anterior margin and 3 groups of serrated setae in posterior margin; distal margin of palm (Fig. 8e) almost straight, slightly oblique, with double row of 6 inner and 7 outer bifurcate robust setae; palmar groove (depression) feebly developed, with 5 inner and 6 outer robust setae; dactylus with 3 outer setae.

Gnathopod II (Fig. 8f): coxal plate sub-rectangular, with 7 apical and numerous facial setae, width/depth ratios is 0.75 ; basis width/length ratio is $0.36 / 1$, with 5 long setae inserted along posterior margin and with 3 medium simple setae in anterior margin; ischium with 2 short simple setae; merus with 4 distal setae; carpus is $0.64 \mathrm{X}$ of length of basis and $0.57 \mathrm{X}$ of propodus, with 1 anterior simple seta and 1 group of plumose posterior seta; propodus $1.37 \mathrm{X}$ longer than broad, with 1-2 simple anterior setae, 2 superior medial, 4 inferior medial and 5 groups of posterior setae; palm oblique with a double row of 9 inner and 9 outer bifurcate robust setae of different size; palm groove (depression) feebly developed (Fig. $8 g$ ), palmar corner with 3 strong palmar spiniform setae, 1 supporting spiniform seta on inner surface; dactylus with 5 setae along anterior margin and few short setae along inner margin.

Pereopod III (Fig. 9a): coxal plate sub-rectangular, with 7 apical and numerous facial setae, width/depth ratio is 0.71 ; basis about $3.8 \mathrm{X}$ as long as wide, with long anterior and posterior simple setae; merus about $0.70 \mathrm{X}$ of basis, about $1.50 \mathrm{X}$ of carpus and about $1.32 \mathrm{X}$ of propodus in length; carpus about $0.88 \mathrm{X}$ of propodus in length; dactylus (Fig. $9 b$ ) about $0.42 \mathrm{X}$ of propodus, with 1 plumose seta on outer margin and 1 additional spine accompanying with seta along ventral margin.

Pereopod IV (Fig. 9c): subequal to pereopod III in length; coxal plate expanded and broadly convex distally, posterior margin with shallow excavation, distal margin with 11 apical short setae and numerous facial setae, width/depth ratio 


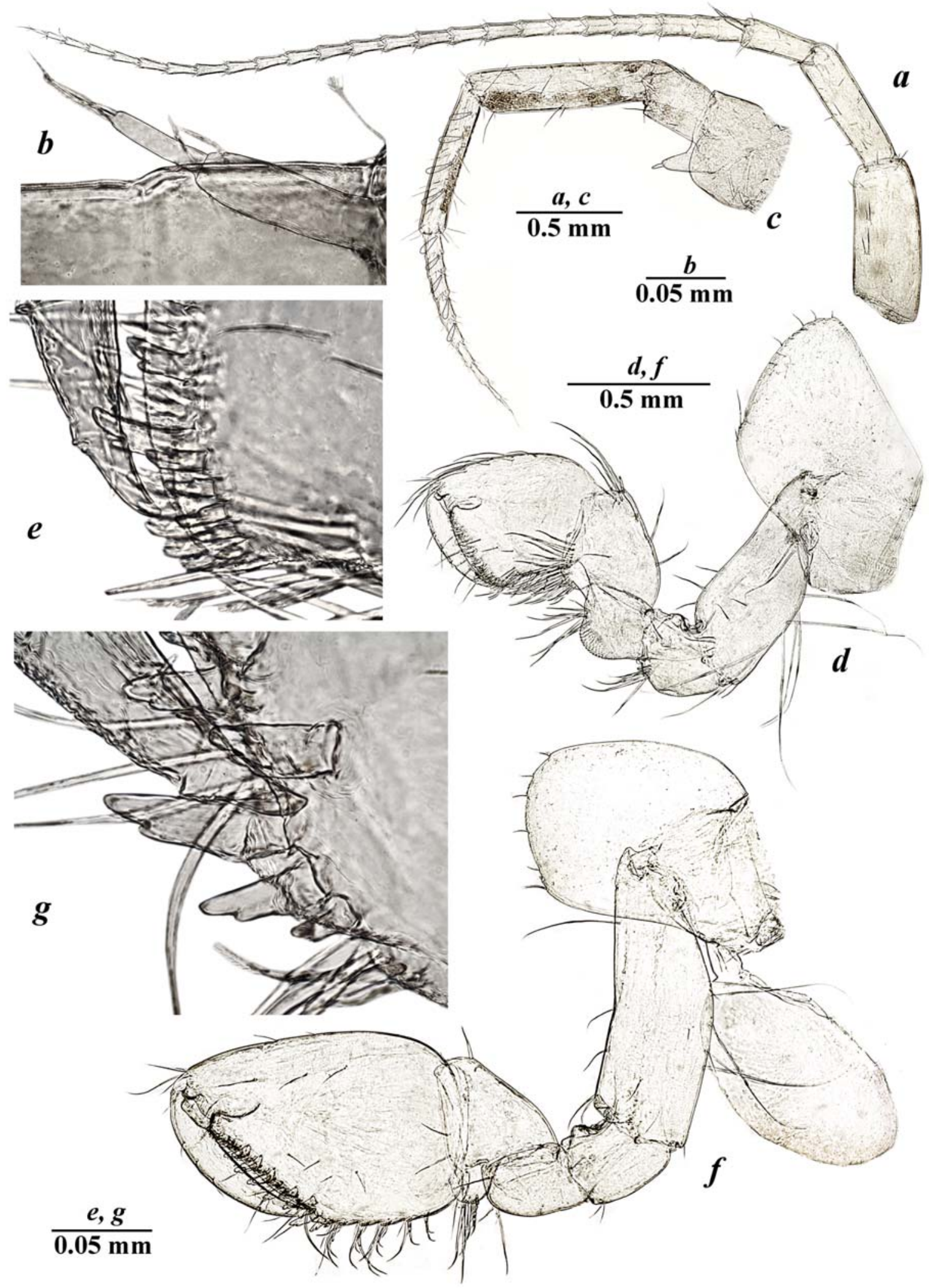

Fig. 7. Pontonyx colchicus Marin et Palatov sp.n., $\sigma^{7}: a-$ antenna I; $b-$ accessory flagellum of antenna I; $c-$ antenna II; $d-$ gnathopod I; $e$ - distoventral palmar margin of chela of GnI; $f$ - gnathopod II; $g$ - distoventral palmar margin of chela of GnII.

Рис. 7. Pontonyx colchicus Marin et Palatov sp.n., $\mathrm{O}^{7}: a$ - антенна I; $b-$ добавочный жгутик антенны I; $c$ - антенна II; $d-$ гнатопода I; $e$ - дистовентральный край ладони клешни $\mathrm{GnI} ; f$ - гнатопода II; $g$ - дистовентральный край ладони клешни GnII. 

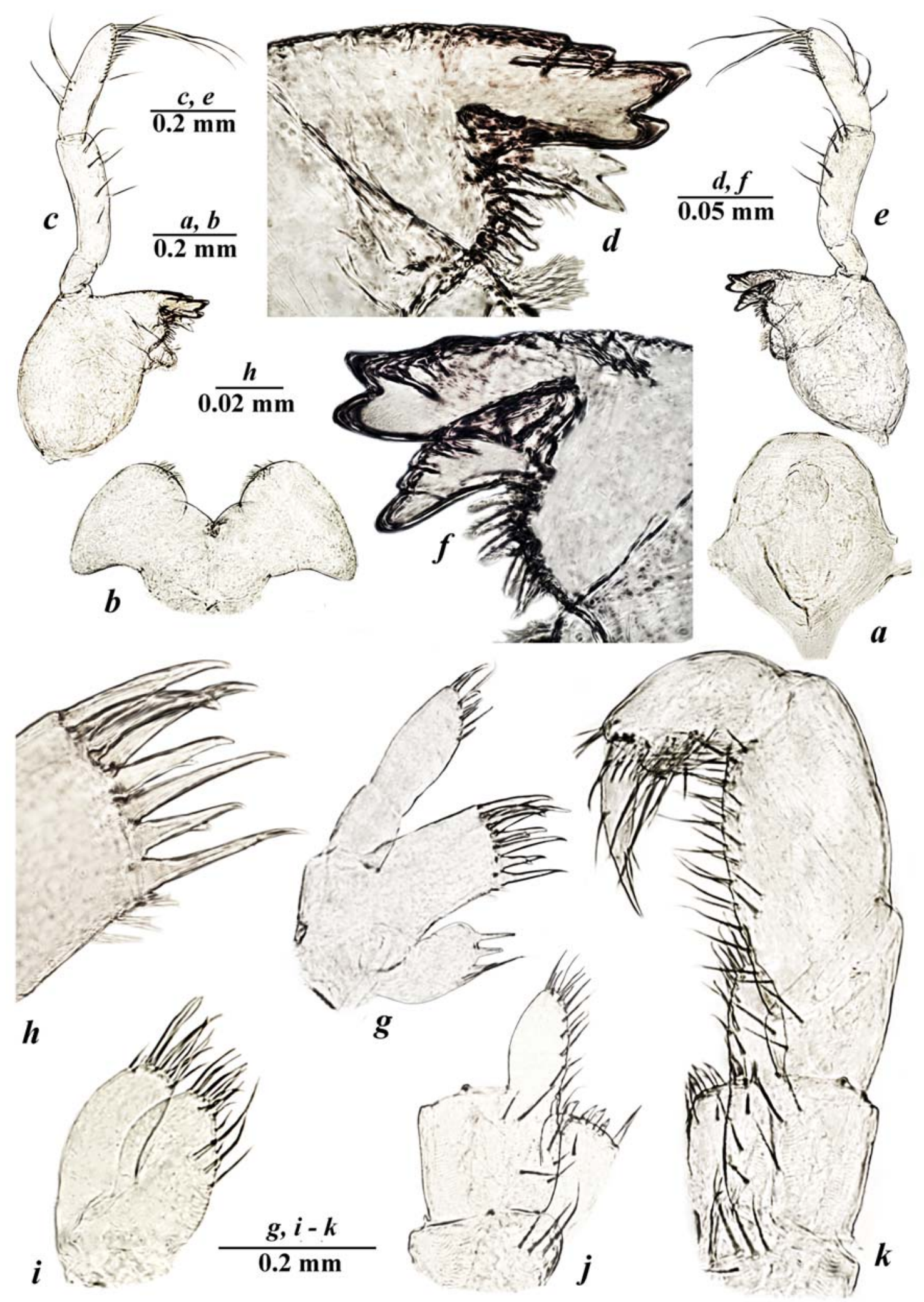

Fig. 8. Pontonyx colchicus Marin et Palatov sp.n., $O^{7}: a$ - labrum (upper lip); $b$ - labium (lower lip); $c$ - left mandible; $d$ - same, incisor process and pars incisiva; $e$ - right mandible; $f$ - same, incisor process and pars incisiva; $g$ - maxilla I; $h$ - distal margin of inner plate of maxilla I; $i$ - maxilla II; $j, k$ - maxilliped.

Pис. 8. Pontonyx colchicus Marin et Palatov sp.n., $0^{7}: a-$ лабрум (верхняя губа); $b-$ лабиум (нижняя губа); $c-$ левая мандибула; $d$ - то же, режущий отросток и резцовая часть; $e$ - правая мандибула; $f$ - то же, режущий отросток и резцовая часть; $g$ - максилла I; $h$ - дистальный край внутренней пластины максилы I; $i$ - максилла II; $j, k$ - максиллипед. 


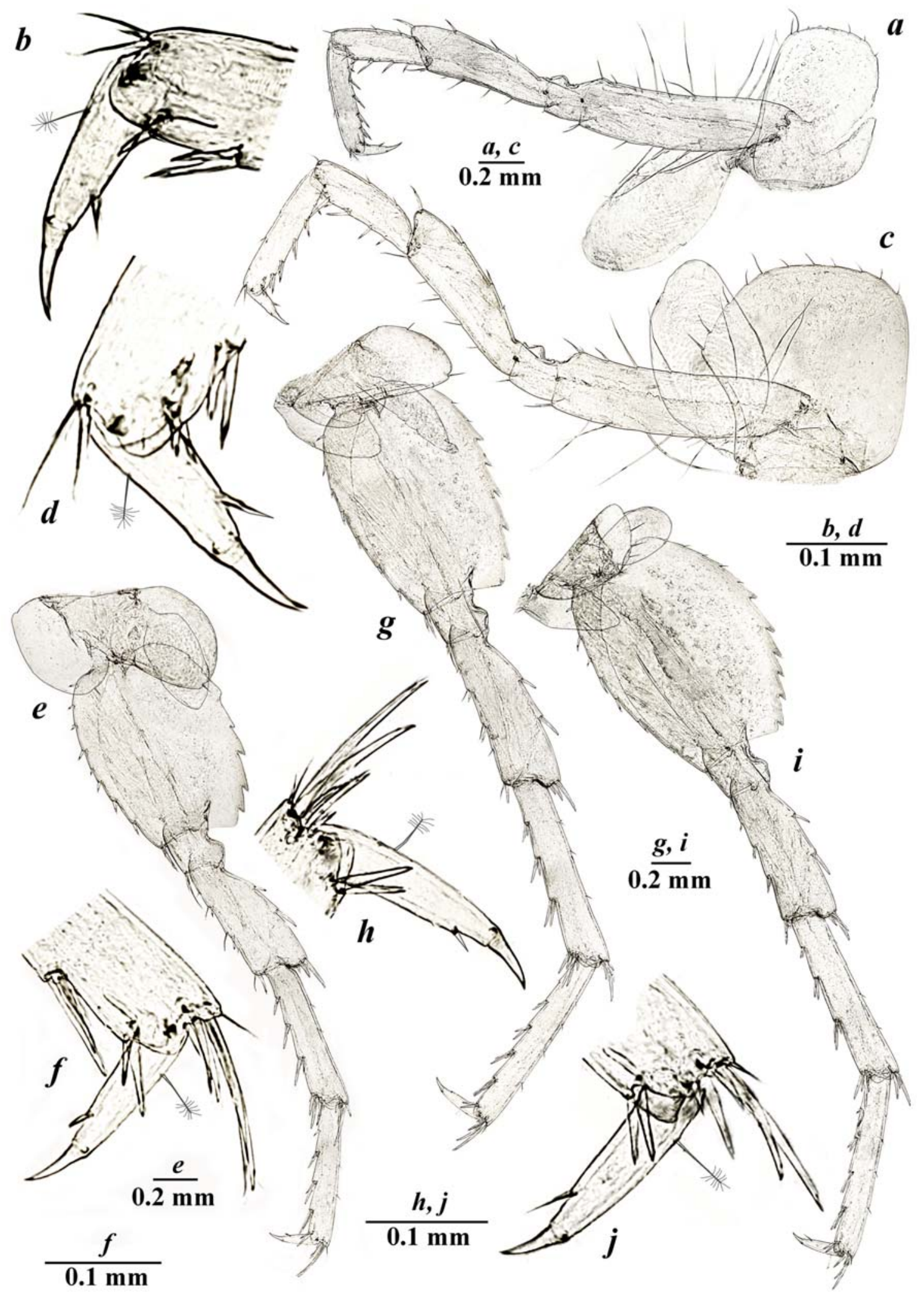

Fig. 9. Pontonyx colchicus Marin et Palatov sp.n., $\sigma^{\top}: a$ - pereopod III; $b$ - dactylus of PIII; $c$ - pereopod IV; $d$ - dactylus of PIV; $e$ - pereopod V; $f$ - dactylus of PV; $g$ - pereopod VI; $h$ - dactylus of PVI; $i$ - pereopod VII; $j$ - dactylus of PVII.

Рис. 9. Pontonyx colchicus Marin et Palatov sp.n., $\sigma^{7}: a$ - переопода III; $b$ - дактилус PIII; $c$ - переопода IV; $d$ - дактилус PIV; $e$ - переопода V; $f$ - дактилус PV; $g$ - переопода VI; $h$ - дактилус PVI; $i$ - переопода VII; $j$ - дактилус PVII. 

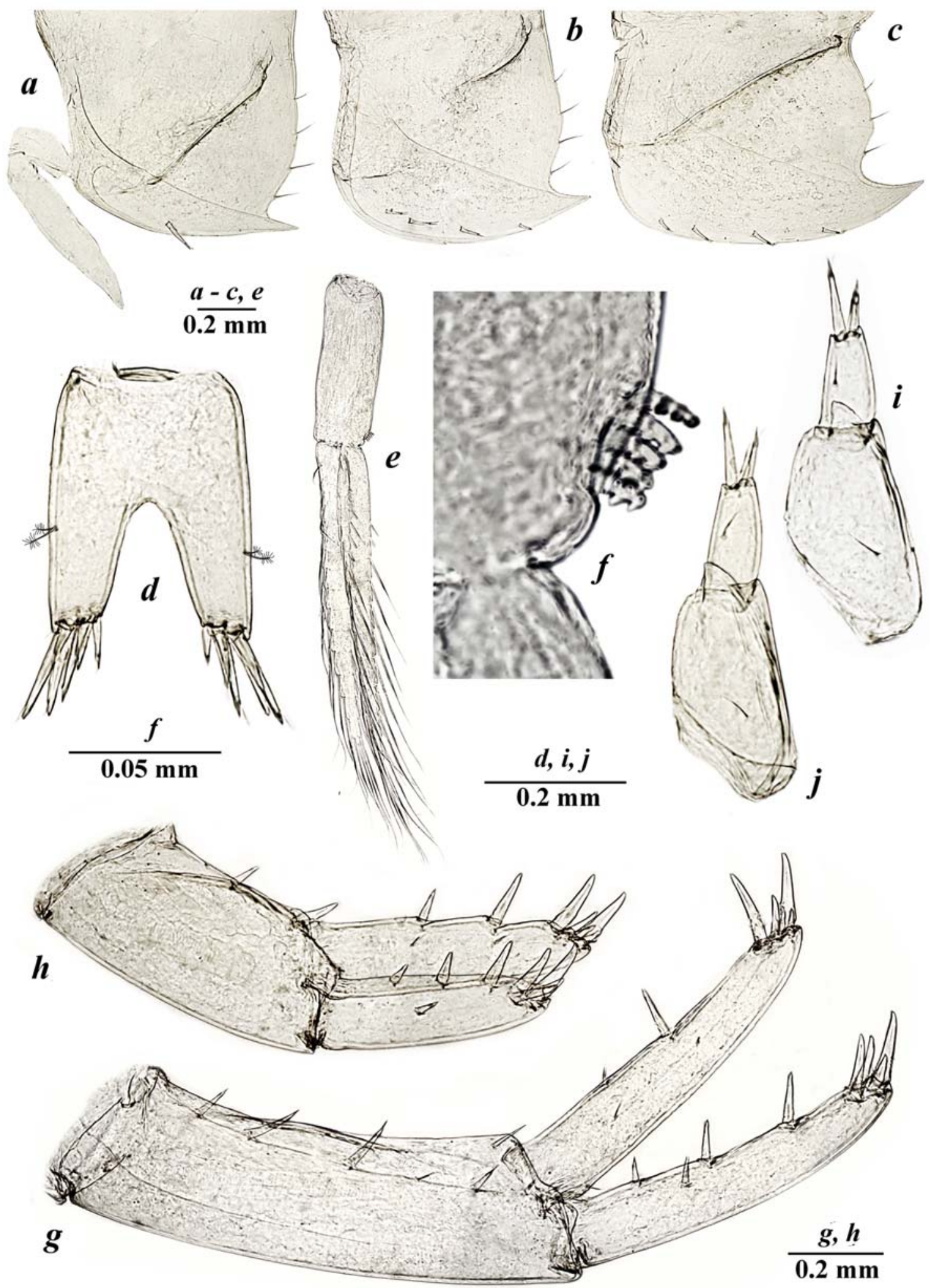

Fig. 10. Pontonyx colchicus Marin et Palatov sp.n., $\sigma^{7}: a$ - epimeral plate I; $b$ - epimeral plate II; $c$ - epimeral plate III; $d$ - telson; $e$ - pleopod III; $f$ - hooks of retinacula of pleopod III; $g$ - uropod I; $g$ - uropod II; $i, j$ - uropod III.

Рис. 10. Pontonyx colchicus Marin et Palatov sp.n., $\mathrm{O}^{7}: a-$ эпимеральная пластинка I; $b-$ эпимеральная пластинка II; $c-$ эпимеральная пластинка III; $d$ - тельсон; $e$ - плеопода III; $f$ - крючки ретинакулы плеоподы III; $g$ - уропода I; $g$ - уропода II; $i, j$ - уропода III. 
is $1 / 1$; basis about $4.0 \mathrm{X}$ as long as wide, with long anterior and posterior simple setae; merus about $0.71 \mathrm{X}$ of basis, about $1.45 \mathrm{X}$ of carpus and about $1.30 \mathrm{X}$ of propodus in length; carpus about $0.89 \mathrm{X}$ of propodus in length; dactylus (Fig. $9 d$ ) about $0.37 \mathrm{X}$ of propodus, with 1 plumose seta on outer margin and 1 additional spine accompanying with seta along ventral margin.

Pereopods V, VI, VII with the length ratio 1/1.36/1.34.

Pereopod V (Fig. 9e): coxal plate large, bilobate with distinct anterior and posterior lobes; posterior and anterior lobes with 1 margin simple seta each, with numerous facial setae; basis about $1.26 \mathrm{X}$ as long as wide, with numerous facial setae, posterior margin slightly convex, armed with 8 shallow serrations, with distinct distal corner, anterior margin with 8 split-tipped robust and 4 distal setae; merus about $0.72 \mathrm{X}$ of basis, $0.89 \mathrm{X}$ of carpus and about $0.94 \mathrm{X}$ of propodus in length; dactylus (Fig. 9f) approximately $0.36 \mathrm{X}$ of propodus, with 1 plumose seta on outer margin and 1 additional spine accompanying with seta along ventral margin.

Pereopod VI (Fig. 9g): coxal plate bilobate, with distinct posterior and vestigial anterior lobes; anterior lobe without setae, posterior lobe with 2 margin setae, each with numerous facial setae; basis about $1.43 \mathrm{X}$ as long as wide, with numerous facial setae, posterior margin convex, armed with 9 shallow serrations, anterior margin with 7 split-tipped robust and 3 distal setae; merus about $0.80 \mathrm{X}$ of basis, about $0.90 \mathrm{X}$ of carpus and propodus in length; dactylus (Fig. 9h) approximately $0.30 \mathrm{X}$ of propodus, with 1 plumose seta on outer margin and 1 additional spine accompanying with seta along ventral margin.

Pereopod VII (Fig. 19i): coxal plate small, semi-lunar, with 4 posterior seta; basis about $1.31 \mathrm{X}$ as long as wide, with numerous facial setae, posterior margin convex, armed with 11 serrated setae, with distinct distal corner; anterior margin with 7 split-tipped robust and 3 distal setae; merus about $0.71 \mathrm{X}$ of basis, about $0.84 \mathrm{X}$ of carpus and about $0.86 \mathrm{X}$ of propodus in length; dactylus (Fig. 9j) approximately $0.28 \mathrm{X}$ of propodus in length, with 1 plumose seta on outer margin and 1 additional spine accompanying with seta along ventral margin.

Gills, brood plates (Fig. 9): coxal gills on somites IIVII, somites V-VII with lanceolate sternal gill on each. Coxal gills of PII-PVII ovoid, gills/bases pereopod ratios are $0.82 / 1,0.82 / 1,0.91 / 1,0.55 / 1,0.54 / 1$ and $0.33 / 1$, respectively.

Pleopods (Fig. 10e). Pleopod I peduncle with 4 coupling hooks in retinacula, without lateral setae; outer and inner rami with 14 and 16 segments, respectively. Pleopod II peduncle with 5 coupling hooks in retinacula, without setae; outer and inner rami with 12 and 14 segments, respectively. Pleopod III peduncle with 4-5 coupling hooks in retinacula, without lateral setae (Fig. 10e,f); outer and inner rami with 9 and 11 segments, respectively.

Epimera. Epimeron I (Fig. 10a) distally produced and sharply pointed, ventral margin with 1 spine, posterior margin convex, with 4 setae. Epimeron II (Fig. 10b) distally produced and sharply pointed, ventral margin armed with 4 spines, posterior margin convex, with 4 setae. Epimeron III (Fig. 10c) distally produced and sharply pointed, ventral margin armed with 4 spines, posterior margin convex, with 3 setae.

Urosomites completely fused, smooth.

Uropod I (Fig. 10g): peduncle about 3.6X as long as wide, with dorsointernal row of 6 thin short spines, 1 subdistal short spine and 1 dorsoexternal thin short spine; ex- opodite subequal of endopodite in length; endopodite not paddle-like, with 2 dorsolateral, 5 apical spines; exopodite with 3-4 dorsolateral and 5 apical spines.

Uropod II (Fig. 10h): peduncle about 1.9X as long as wide, subequal of endopodite in length, with 2 outer short spines; exopodite about $0.84 \mathrm{X}$ of endopodite in length, with 3 outer and 5 apical robust spines; endopodite with 2 outer and 5 apical robust spines.

Uropod III (Fig. 10i, $j$ ): uniramous, peduncle coneshaped, about $1.8 \mathrm{X}$ as long as wide, with a terminal "pointed knob; apical margin of ramus armed with 3 spines.

Telson (Fig. 10d): not tapered distally, elongate, 0.63X as long as broad, as long as uropod III; apical margin cleft about $1 / 2$ of total length; with mix of 5 short and long spines and with 2 additional submarginal plumose setae on each lobe.

COLORATION. The body and appendages yellowish or grayish transparent; well-pigmented black eyes well seen.

GENBANK ACCESSION NUMBERS. MZ449248, MZ449249.

TAXONOMIC REMARKS. The new species can be clearly separated from $P$. odessana (after Sidorov \& Kovtun [2015]) in the following features: 1) well-developed, large eyes and a distinctly pigmented body (vs. small, rudimentary eyes and a depigmented body in $P$. odessana); 2) posteroventral corners of EpI-III with sharp and large spines (vs. posteroventral corners of EpI-III with small and short spines in P. odessana); 3 ) inner plate of MxII with oblique row of 3 short plumose setae (vs. inner plate of MxII with oblique row of 5 plumose setae in $P$. odessana); 4) relatively short AI with 24 segments, which are about $60 \%$ of the total body length (vs. AI with 32 segments, being about $90 \%$ of total body length in $P$. odessana).

Pontonyx colchicus sp.n. can be easily differed from $P$. osellai (after Ruffo [1972]) by: 1) smaller body size (the largest collected $\sigma^{7}$ has bl. $8.0 \mathrm{~mm}$ ) (vs. the largest $\sigma^{7}$ has bl. $10.5 \mathrm{~mm}$ in $P$. osellai); 2) left mandible with a row of 6 robust plumose accessory setae, right mandible with a row of 4 robust plumose setae (vs. left and right mandibles with a row of 8 robust plumose accessory setae in $P$. osellai); 3 ) segment 3 of mandibular palps with $10-11$ separate Dsetae, 1 C-seta and 3 B-setae (vs. 12-13 separate D-setae, 4 C-setae and 5 B-setae in P. osellai); 4) 2-3 medium simple setae in anterior margin of basis of PII (vs. 10-11 long simple setae in $P$. osellai); 5) longer outer and inner rami of pleopod I with 14 and 16 segments (vs. 11 and 14 segments in P. osellai, respectively).

Pontonyx colchicus sp.n. can be easily differed from Pontonyx adjaricus sp.n. in the following features: 1) larger body size (the largest $\sigma^{7}$ has bl. $8.0 \mathrm{~mm}$ ) (vs. the largest $\sigma^{7}$ has bl. $4.3 \mathrm{~mm}$ in Pontonyx adjaricus sp.n.); 2) 9-segmented flagellum of AII (vs. 6-segmented in Pontonyx adjaricus sp.n.); 3) larger gills of PII-PIV with the ratios of gills/ bases of pereopods are $0.82 / 1,0.82 / 1,0.91 / 1$, respectively (vs. $0.75 / 1,0.76 / 1,0.72 / 1$ in Pontonyx adjaricus sp.n., respectively); 4) wider propodus of PII, which is about $1.37 \mathrm{X}$ longer than broad (vs. 1.5 longer than broad in Pontonyx adjaricus sp.n.); 5) longer outer and inner rami of pleopod I with 14 and 16 segments (vs. 10 and 12 segments in Pontonyx adjaricus sp.n., respectively).

DISTRIBUTION AND ECOLOGY. The species is presently known as strictly endemic, living in a small pond near road Chaladidi-Kulevi-Poti $\left(42^{\circ} 11^{\prime} 42.0^{\prime \prime} \mathrm{N} 41^{\circ} 42^{\prime} 19.9^{\prime \prime} \mathrm{E}\right)$, Khobi Municipality, Samegrelo-Zemo Svaneti, Georgia. 
Genus Synurella Wrześniowski, 1877

INCLUDED SPECIES. Synurella ambulans (F. Müller, 1846) (the type species of the genus), S. behningi (Birštein, 1948), S. longidactylus S. Karaman, 1929, S. donensis (Martynov, 1919), S. tenebrarum (Wrześniowski, 1888), S. coeca (Dobreanu et Manolache, 1951), S. intermedia Dobreanu, Manolache et Puscariu, 1952 and S. lepida Mateus et Mateus, 1990.

NON-CONFIRMED SPECIES PRESENTLY INCLUDED IN THE GENUS. Synurella bifurca (O.P. Hay, 1882), Synurella dentata Hubricht, 1943 and S. philareti Birštein, 1948. For example, S. philareti was described from the lower reaches of the Dnieper River [Birštein, 1948]. According to the shape of the epimeral plates and the telson it is very similar to representatives of the genus Pontonyx, but, unfortunately, the presented original description does not allow us to identify it for sure.

DIFFERENTIAL DIAGNOSIS. The genus Synurella is well distinguished from all other Palearctic crangonyctid genera by the following features: 1) pigmented body with well-developed pigmented eyes (vs. depigmented in Crangonyx, Amurocrangonyx, Diasynurella and Palearcticarellus); 2) completely fused urosomal segments (vs. free urosomal segments in Amurocrangonyx, Crangonyx and Palearcticarellus; urosomal segments 2-3 are partially fused in Diasynurella); 3) trapezoidal or subquadrate propodus of pereopod I (vs. oval propodus of pereopod I in Amurocrangonyx, Crangonyx and Palearcticarellus); 4) the presence of a row of 3-5 bifurcated closing bristles along the inner surface of the distoventral palmar corner of propodus of pereopod II (vs. 1-2 simple single strong bristles, not organized in a row in Pontonyx); 5) vestigial two-segmented uropod III (vs. well-developed two-segmented uropod III in Amurocrangonyx and Crangonyx; mostly reduced uni-segmented in Lyurella); 6) the absence of an additional terminal knob on peduncle of uropod III (vs. present in Pontonyx and Volgonyx); 7) simple endopodite of uropod I (vs. paddlelike in Volgonyx); 8) a single additional spine-like setae on dactyli of pereopods III-VII (vs. Amurocrangonyx, Eosynurella and Lyurella); 9) 2 hooks in retinacula of pleopods (vs. more than 2 hooks in Amurocrangonyx, Crangonyx, Lyurella, Eosynurella, Pontonyx, Palearcticarellus and Volgonyx); 10) developed inner lobes of labium (vs. completely reduced in Eosynurella).

\section{Synurella ispani Palatov et Marin sp.n. Figs 1, 11-15.}

MATERIAL EXAMINED. Holotype, + (bl. $5.5 \mathrm{~mm}$ ), ZMMU Mb-1214, Georgia, Republic of Ajaria (Adjara), Kobuleti, a small stream in the Ispani peat bog, in the western part of the Kobuleti National Reserve, $41^{\circ} 51^{\prime} 41.63^{\prime \prime} \mathrm{N} 41^{\circ} 47^{\prime} 8.94^{\prime \prime} \mathrm{E}$, coll. D. Palatov, 30.01.2013. Paratypes. 2ㅇ (bl. 5.0 and $5.3 \mathrm{~mm}$ ), ZMMU Mb1215 , same locality and data as holotype.

ADDITIONAL MATERIAL. 4 OO, Georgia, Republic of Ajaria (Adjara), Kobuleti, Ispani 1 peat bog, $41^{\circ} 51^{\prime} 29^{\prime \prime} \mathrm{N}, 41^{\circ} 47^{\prime} 15^{\prime \prime} \mathrm{E}$, site 1: Sphagnum/mounds, $150 \mathrm{~m}$ E of NE peat bog edge, sinking (pools/wet Sphagnum btw. mounds), 30.04.2019, coll. A. Przhiboro; 2 우, same locality, pitfall traps, $8-10.10 .2019$, coll. A. Przhiboro; 13 우, same locality, small im-mires lake, $41^{\circ} 51^{\prime} 16.33^{\prime \prime} \mathrm{N}$, $41^{\circ} 47^{\prime} 28.12^{\prime \prime} \mathrm{E}, 20.05 .2019$, coll. A. Prokin.

ETYMOLOGY. The new species is named after the type locality, the Ispani peat bog, located in the Kobuleti National Reserve, Kobuleti, Republic of Ajaria (Adjara), Georgia, where the species was discovered.
DESCRIPTION. Body (Fig. 1): moderately stout; the largest collected + has bl. $5.5 \mathrm{~mm}$.

Antenna I (Fig. 11a) about 50\% of body length, about $1.8 \mathrm{X}$ longer than antenna II; primary flagellum with 11 segments, with aesthetascs on distal segments; accessory flagellum 2-segmented, distal segment about 3.0X shorter than basal one (Fig. 11b).

Antenna II (Fig. 11c): gland clone distinct, distally pointed; peduncle about 2.0-2.1X longer than flagellum, with robust setae tightly covering segments 3 and 4 , peduncle of segment 4 about 1.1-1.2X longer than segment 5; flagellum 7-segmented, without calceoli.

Mandible (Fig. 12c-e): left mandible (Fig. 12c, d) incisor 5 -dentate, lacinia mobilis 5 -dentate, with 4 robust plumose accessory setae; molar process with 1 seta. Right mandible (Fig. 12e,f) incisor 4-dentate, lacinia mobilis toothed, triturative, lobes with numerous protuberances; underlying with row of 2-3 robust plumose setae; molar process similar to left mandible. Palp 3-segmented, segment 2 with 7-8 setae; segment 3 about 3.0X longer than wide, with convex margins, with 10-11 separate D-setae, 2-3 C-setae, 1 B-seta and 3-4 separate E-setae (Fig. 12c,e).

Labrum (upper lip) (Fig. 12a): oval, apical margin with numerous small fine setae.

Labium (lower lip) (Fig. 12b): inner lobes feebly developed.

Maxilla I (Fig. 12g): inner plate with 7-8 plumose marginal setae, outer plate with 7 apical comb-spines (Fig. 12h); palp 2-segmented, distal segment pubescent, about $2.5 \mathrm{X}$ of basal segment, apical margin of distal segment with 8-9 bifurcated and 4 simple setae.

Maxilla II (Fig. 12i): inner and outer plates subequal in length, weakly narrowing distally, with 13 apical setae, covered in pubescent setae; inner plate narrowing slightly distally, with group of dense short setae on apex, with oblique row of 8 short plumose setae.

Maxilliped (Fig. 12j): inner plate much shorter than outer plate, with 2 spines, 1 robust plumose and 1 simple setae apically, and 5 robust plumose setae laterally; outer plate narrow, with a double row of 24 medial stiff simple setae of different length; palp quadriarticulate, article 1 without setae on outer margin, article 2 with a row of 24 simple setae on inner margin and $0-1$ seta on outer margin, article 3 sub-quadrate; dactylus with 1 seta on outer margin and with 2 thin setae at inner margin, nail long, slender, with 2 thin setae at hinge.

Gnathopod I (Figs 11d; 15a): smaller than gnathopod II; coxal plate sub-rectangular, distally rounded, with 9 apical and numerous facial setae, width/depth ratio is $0.56-0.60$; basis width/length ratio is $0.3 / 1$, without setae on anterior margin, 5 long setae on inner face and 4 long setae on posterior margin; merus with 14 distal setae; carpus is $0.42 \mathrm{X}$ of basis and $0.50 \mathrm{X}$ of propodus, with 13-14 serrated setae in inner margin and 6 simple setae in outer margin; propodus $1.5 \mathrm{X}$ longer than broad, with 5 simple setae in anterior margin and 7 serrated setae in posterior margin; distal margin of palm almost straight, slightly oblique, with double row of 6 inner and 6 outer bifurcate robust setae; palmar groove (depression) (Figs $11 e ; 15 b$ ) feebly developed, with 4 inner and 4 outer robust setae; dactylus with 1 outer seta.

Gnathopod II (Figs 11f; 15c): coxal plate sub-rectangular, with 9 apical and numerous facial setae, width/depth ratios is 0.60 ; basis width/length ratio is $0.30 / 1$, with several (4-5) long setae inserted along posterior margin and with 12 simple setae in anterior margin; ischium with 3 short simple setae; merus with 6 distal setae; carpus is $0.35 \mathrm{X}$ of 


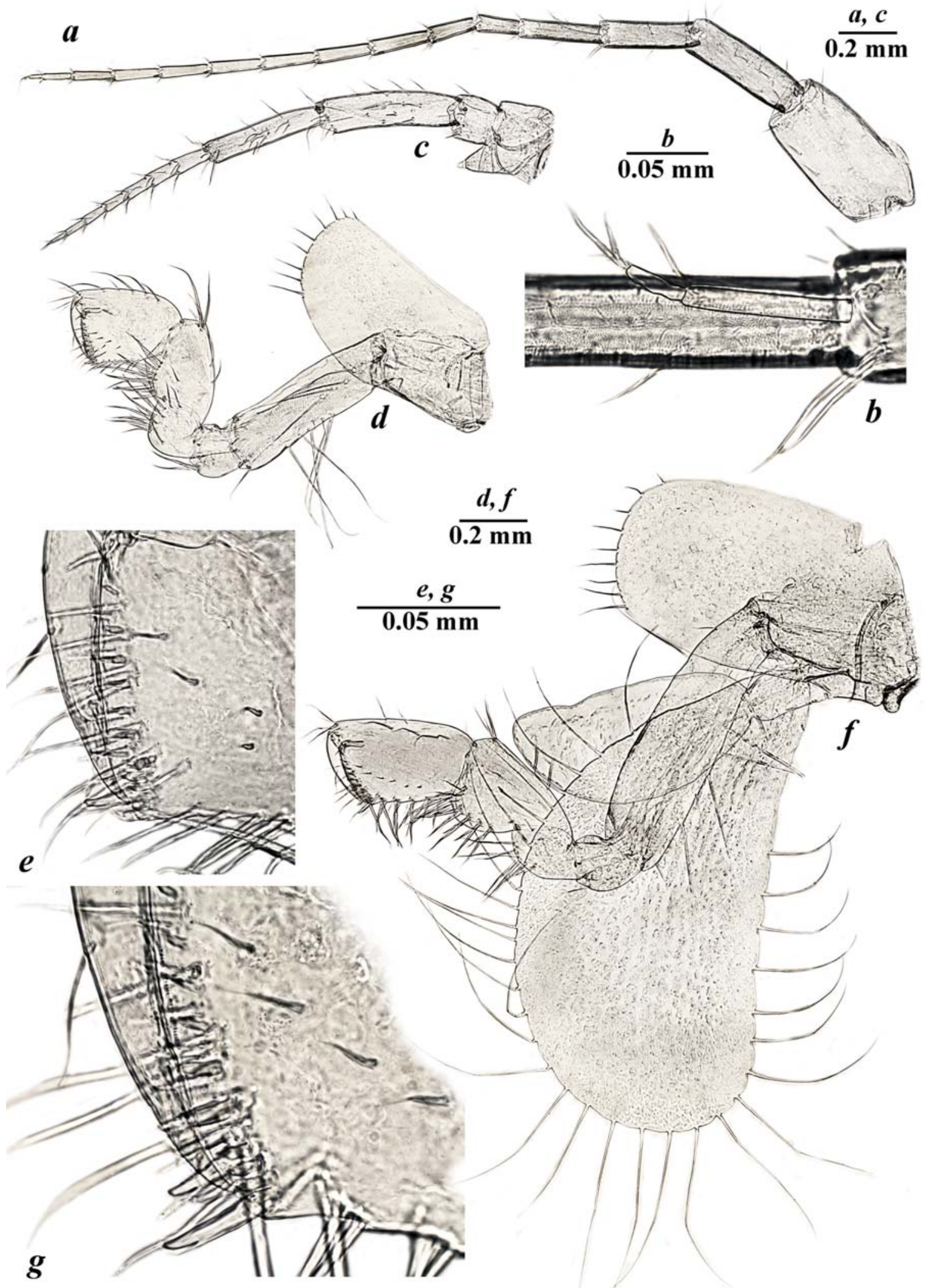

Fig. 11. Synurella ispani Palatov et Marin sp.n., o : $a$ - antenna I; $b-$ accessory flagellum of antenna I; $c$ - antenna II; $d-$ gnathopod I; $e$ - distoventral palmar margin of chela of GnI; $f$ - gnathopod II; $g$ - distoventral palmar margin of chela of GnII.

Рис. 11. Synurella ispani Palatov et Marin sp.n.,,$: a-$ антенна I; $b$ - добавочный жгутик антенны I; $c$ - антенна II; $d-$ гнатопода I; $e$ - дистовентральный край ладони клешни GnI; $f$ - гнатопода II; $g$ - дистовентральный край ладони клешни GnII. 


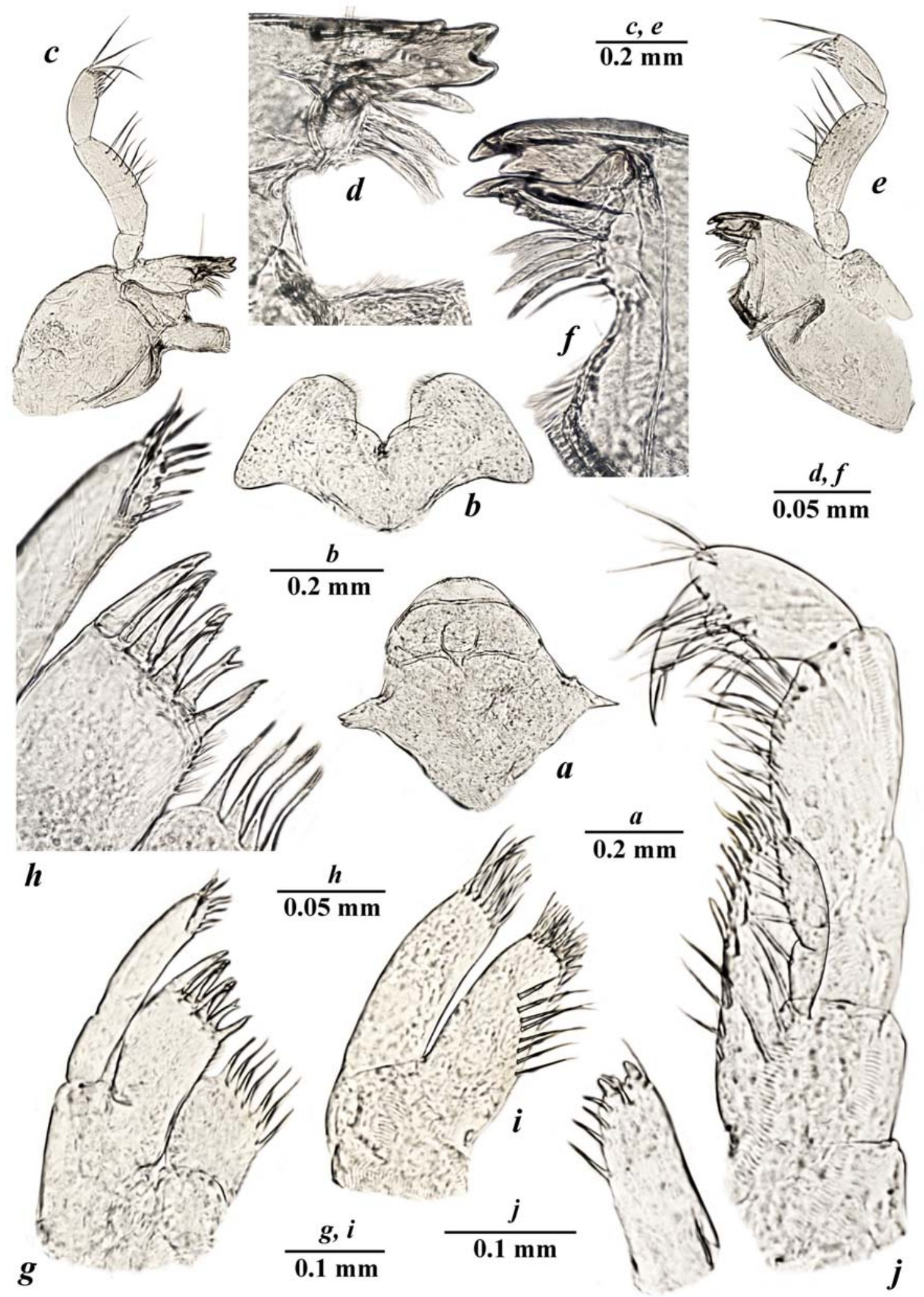

Fig. 12. Synurella ispani Palatov et Marin sp.n., $+: a$ - labrum (upper lip); $b$ - labium (lower liç); $c$ - left mandible; $d$ - same, incisor process and pars incisiva; $e$ - right mandible; $f$ - same, incisor process and pars incisiva; $g$ - maxilla $\mathrm{I} ; h$ - distal margin of inner plate of maxilla I; $i$ - maxilla II; $j, k$ - maxilliped.

Pис. 12. Synurella ispani Palatov et Marin sp.n., ㅇ: $a$ - лабрум (верхняя губа); $b$ - лабиум (нижняя губа); $c$ - левая мандибула; $d$ - то же, режущий отросток и резцовая часть; $e$ - правая мандибула; $f$ - то же, режущий отросток и резцовая часть; $g$ максилла I; $h$ - дистальный край внутренней пластины максиллы I; $i$ - максилла II; $j, k$ - максиллипед. 


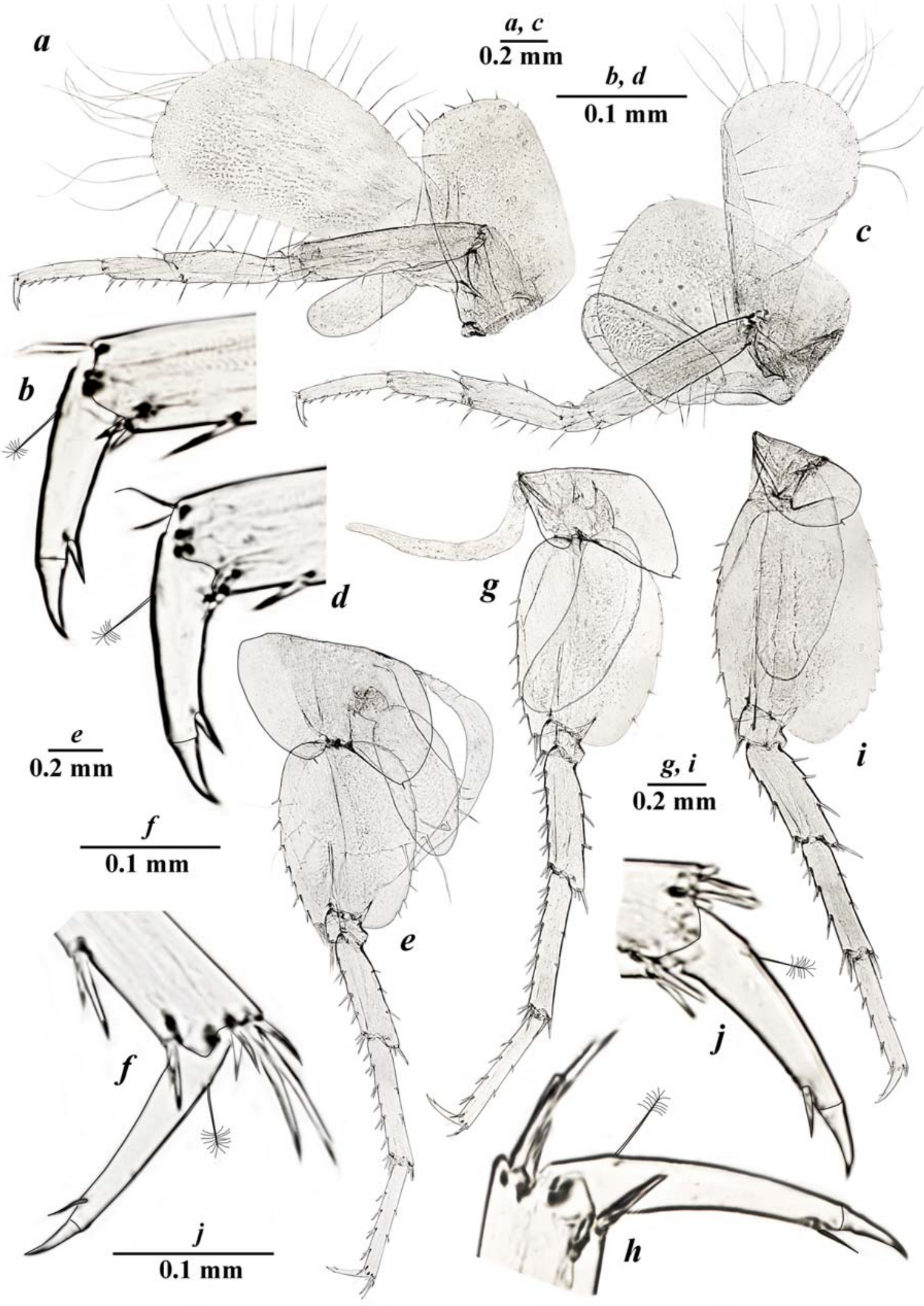

Fig. 13. Synurella ispani Palatov et Marin sp.n., $+: a$ - pereopod III; $b$ - dactylus of PIII; $c$ - pereopod IV; $d$ - dactylus of PIV; $e$ pereopod V; $f$ - dactylus of PV; $g$ - pereopod VI; $h$-dactylus of PVI; $i$ - pereopod VII; $j$ - dactylus of PVII.

Рис. 13. Synurella ispani Palatov et Marin sp.n., o : $a$ - переопода III; $b$ - дактилус PIII; $c$ - переопода IV; $d$ - дактилус PIV; $e-$ переопода V; $f$ - дактилус PV; $g$ - переопода VI; $h$ - дактилус PVI; $i$ - переопода VII; $j$ — дактилус PVII. 

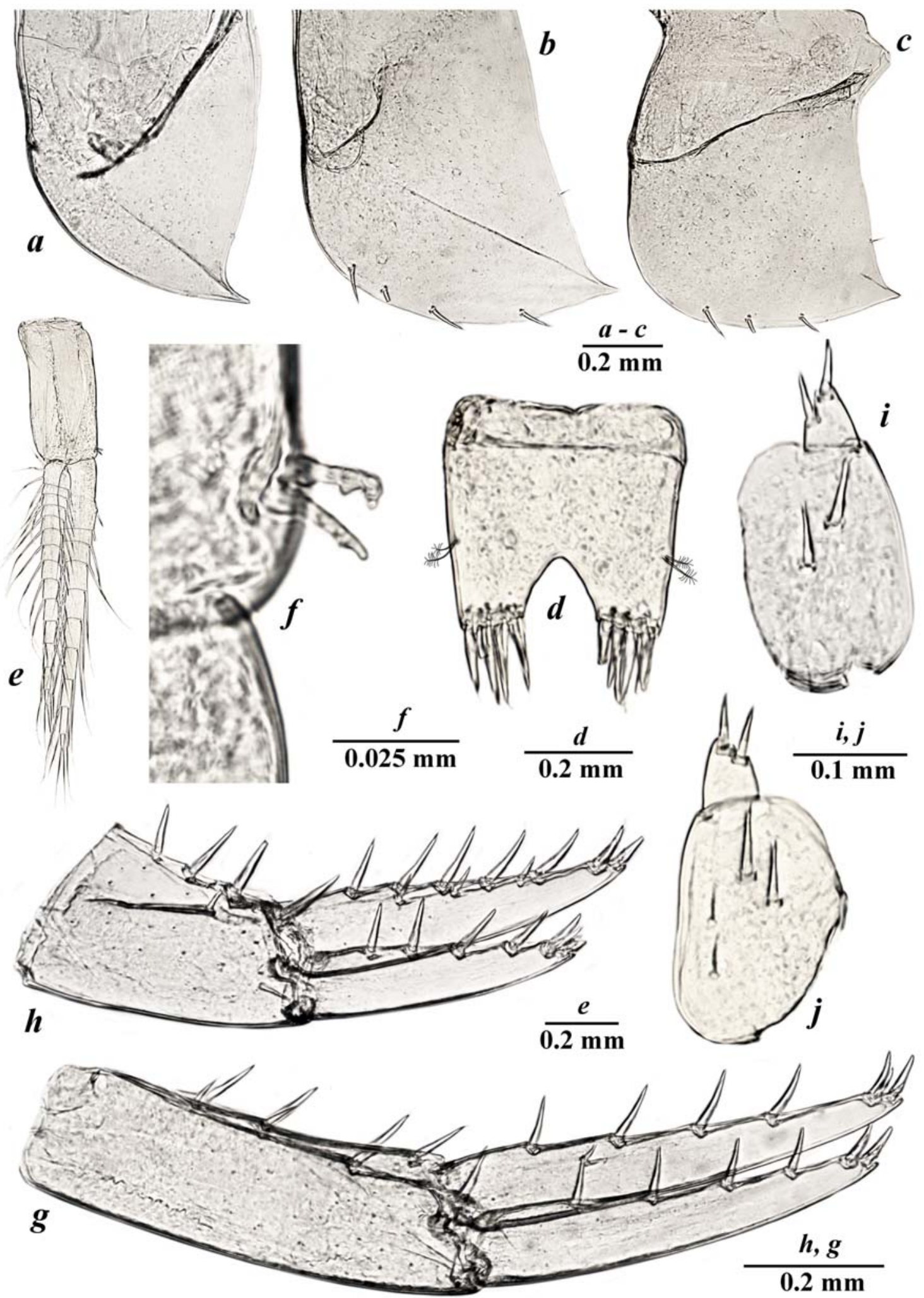

Fig. 14. Synurella ispani Palatov et Marin sp.n.,,$: a$ - epimeral plate I; $b$ - epimeral plate II; $c$ - epimeral plate III; $d$ - telson; $e-$ pleopod III; $f$ - hooks of retinacula of pleopod III; $g$ - uropod I; $h$ - uropod II; $i, j$ - uropod III.

Pис. 14. Synurella ispani Palatov et Marin sp.n., $+: a-$ эпимеральная пластинка I; $b-$ эпимеральная пластинка II; $c-$ эпимеральная пластинка III; $d$ - тельсон; $e$ - плеопода III; $f$ - крючки ретинакулы плеоподы III; $g$ - уропода I; $h$ - уропода II; $i, j$ - уропода III. 


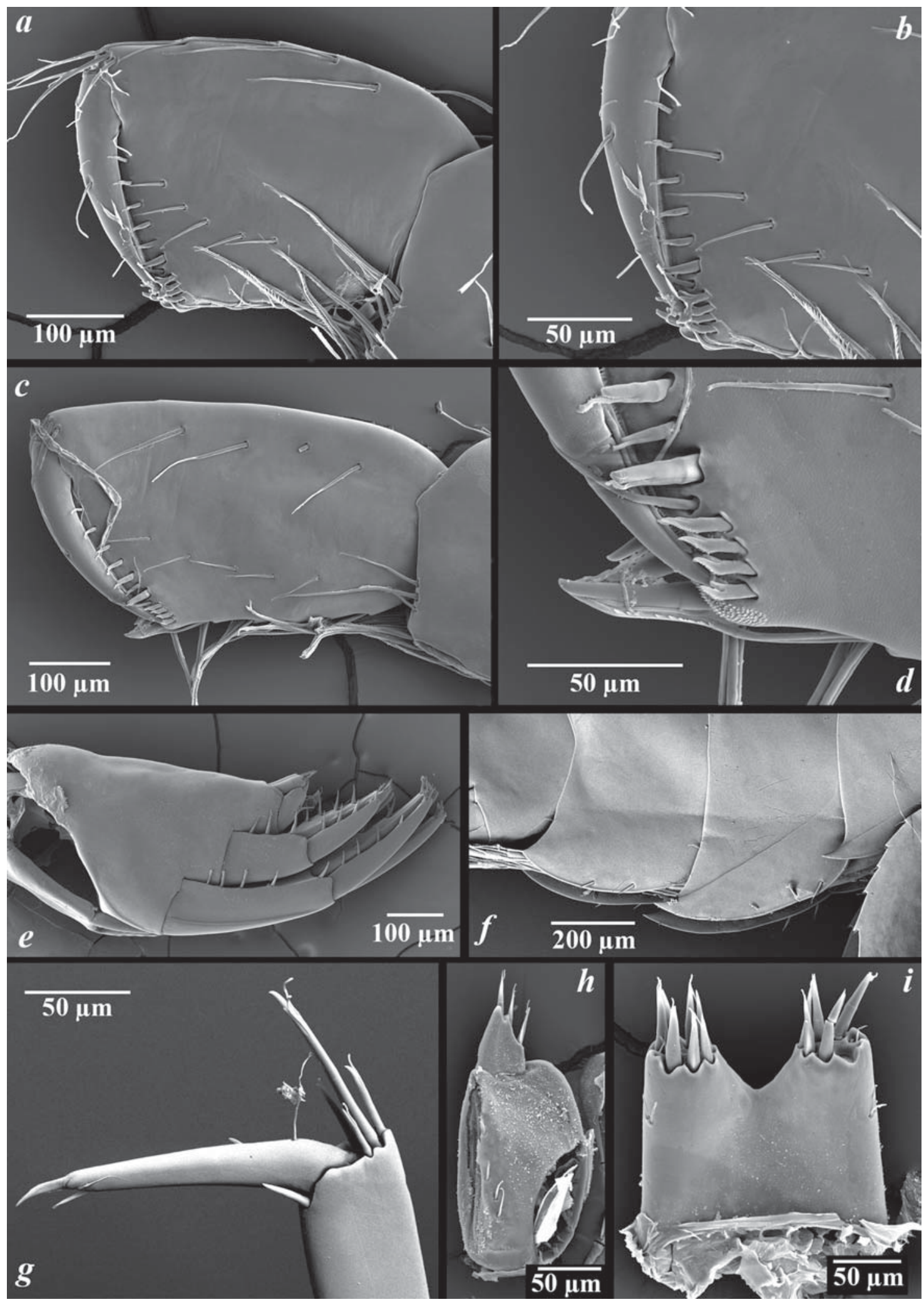

Fig. 15. Synurella ispani Palatov et Marin sp.n., $+: a-$ gnathopod I; $b-$ distoventral palmar margin of chela of GnI; $c$ - gnathopod II; $d$ - distoventral palmar margin of chela of GnII; $e$ - urosomal segments; $f$ - epimeral plates; $g$ - dactylus of pereopod VI; $h$ uropod III; $i$ - telson.

Рис. 15. Synurella ispani Palatov et Marin sp.n., : $a$ - гнатопода I; $b-$ дистовентральный край ладони клешни GnI; $c-$ гнатопода II; $d$ - дистовентральный край ладони клешни $\mathrm{GnII} ; e$ - уросомальные сегменты; $f$ - эпимеральные пластины; $g$ дактилус PVI; $h$ - уропода III; $i$ - тельсон. 
length of basis and $0.70 \mathrm{X}$ of propodus, with 3-4 anterior simple setae and 3 groups of plumose posterior setae; propodus 1.7X longer than broad, with 2 simple anterior setae, 2 4 superior medial, 4-5 inferior medial and 4 groups of posterior setae; palm oblique with a double row of 7 inner and 7 outer bifurcate robust setae; palm groove (depression) (Figs $11 g ; 15 d$ ) feebly developed, with 4 inner and 4 outer robust setae; dactylus without inner and 1 outer seta.

Pereopod III (Fig. 13a): coxal plate sub-rectangular, with 7 apical and numerous facial setae, width/depth ratio is 0.60 ; basis about 4.0-4.2X as long as wide, with long anterior and posterior simple setae; merus about $0.58 \mathrm{X}$ of basis, about $1.4 \mathrm{X}$ of carpus and about $1.2 \mathrm{X}$ of propodus in length; carpus about $0.84 \mathrm{X}$ of propodus in length; dactylus (Fig. $13 \mathrm{~b}$ ) about $0.32 \mathrm{X}$ of propodus in length, with 1 plumose seta on outer margin and 1 additional spine accompanying with seta along ventral margin.

Pereopod IV (Fig.13c): subequal to pereopod III in length; coxal plate expanded and broadly convex distally, posterior margin with shallow excavation, distal margin with 16-17 apical short setae and numerous facial setae, width/ depth ratio is $1.17-1.20 / 1$; basis about $4.5 \mathrm{X}$ as long as wide, with long anterior and posterior simple setae; merus about $0.58 \mathrm{X}$ of basis, about $1.28 \mathrm{X}$ of carpus and about $1.16 \mathrm{X}$ of propodus in length; carpus about $0.9 \mathrm{X}$ of propodus in length; dactylus (Fig. 13d) about $0.33 \mathrm{X}$ of propodus in length, with 1 plumose seta on outer margin and 1 additional spine accompanying with seta along ventral margin.

Pereopods V, VI, VII with the length ratio 1/1.16/1.01.

Pereopod V (Fig. 13e): coxal plate large, bilobate with distinct anterior and posterior lobes; anterior and posterior lobes with 1 marginal simple seta each, with numerous facial setae; basis about $1.38 \mathrm{X}$ as long as wide, with numerous facial setae, posterior margin slightly convex, armed with 11 shallow serrations, with distal corner, anterior margin with 7 split-tipped robust and 4 distal setae; merus about $0.64 \mathrm{X}$ of basis, $0.91 \mathrm{X}$ of carpus and subequal of propodus in length; dactylus (Fig. 13f) approximately $0.35 \mathrm{X}$ of propodus in length, with 1 plumose seta on outer margin and 1 additional spine accompanying with seta along ventral margin.

Pereopod VI (Fig. 13g): coxal plate bilobate, with distinct posterior and vestigial anterior lobes; anterior lobe without setae, posterior lobe with 1 margin seta, each with numerous facial setae; basis about $1.45 \mathrm{X}$ as long as wide, with numerous facial setae, posterior margin convex, armed with 7 shallow serrations, anterior margin with 6 split-tipped robust and 4 distal setae; merus about $0.67 \mathrm{X}$ of basis, $0.97 \mathrm{X}$ of carpus and 1.04X of propodus; dactylus (Figs 13 $h ; 15 g$ ) approximately $0.35 \mathrm{X}$ of propodus in length, with 1 plumose seta on outer margin and 1 additional spine accompanying with seta along ventral margin.

Pereopod VII (Fig. 13i): coxal plate small, semi-lunar, with 1 posterior seta; basis about $1.45 \mathrm{X}$ as long as wide, with numerous facial setae, posterior margin convex, armed with 10 serrated setae and with distinct distal lobe, anterior margin with 7 split-tipped robust and 3 distal setae; merus about $0.51 \mathrm{X}$ of basis, about $0.96 \mathrm{X}$ of carpus and subequal of propodus in length; dactylus (Fig. 13j) approximately $0.34 \mathrm{X}$ of propodus in length, with 1 plumose seta on outer margin and 1 additional spine accompanying with seta along ventral margin.

Gills, Brood Plates (Fig. 13): coxal gills on somites IIVII, somites V-VII with lanceolate sternal gill on each. Coxal gills II-VII ovoid, gills/bases pereopod ratios are $0.82 / 1,0.64 / 1,0.89 / 1,0.82 / 1,0.93 / 1$ and $0.76 / 1$, respectively. Brood plates on somites II-V slender, setaceous, decreasing in size posteriorly.
Pleopods (Fig. 14e). Pleopod I peduncle with 2 coupling hooks in retinacula, without lateral setae; outer and inner rami with 10 and 14 segments, respectively; basal segment of outer ramus with 2 clothes-pin setae. Pleopod II peduncle with 2 coupling hooks in retinacula, without setae; outer and inner rami with 11 and 14 segments, respectively; basal segment of outer ramus with 2 clothes-pin setae. Pleopod III peduncle with 2 coupling hooks in retinacula, without lateral setae (Fig.14f); outer and inner rami with 8 and 11 segments, respectively; basal segment of outer ramus with 2 clothes-pin setae.

Epimera (Fig. 15f). Epimeron I (Fig. 14a) distally produced and sharped, ventral margin without spines, posterior margin with 1 seta. Epimeron II (Fig. 14b) distally produced and sharped, ventral margin armed with 3 spines, posterior margin with 1 seta. Epimeron III (Fig. 14c) distally produced and sharped, ventral margin armed with 4 spines, posterior margin with 1 seta.

Urosomites completely fused, smooth (Fig. 15e).

Uropod I (Fig. 14g): peduncle about 3.3X as long as wide, with dorsointernal row of 3 robust spines, 1 subdistal spine and 3 dorsoexternal robust spines; exopodite slightly shorter than endopodite; endopodite not paddle-like, with 4 dorsolateral and 5 apical spines, 1 ventral seta; exopodite with 4 dorsolateral and 5 apical spines.

Uropod II (Fig. 14h): peduncle about $0.74 \mathrm{X}$ of endopodite in length, with 1 outer robust and 4 inner robust spines; exopodite about $0.8 \mathrm{X}$ of endopodite in length, with 4 outer and 5 apical robust spines; endopodite with 5 outer and 5 apical robust spines.

Uropod III (Figs 14i, $j ; 15 h$ ): uniramous, peduncle trapezoidal, about $1.5 \mathrm{X}$ as long as wide, with 2 weak spines and 2 simple setae; lateral and apical margin of ramus armed with 2 weak spines.

Telson (Figs 14d, 15i) close to square or trapezoidal, about subequal as long as broad; distal margin with Vshaped distal notch, reaching about $1 / 3-1 / 4$ of its length, each lobe armed with 6 robust spines, with 2 additional submarginal plumose setae.

COLORATION. The body and appendages yellowish or grayish transparent; well-pigmented black eyes well seen.

GENBANK ACCESSION NUMBERS. MZ450805, MZ450806.

TAXONOMIC REMARKS. The new species can be clearly separated from Synurella ambulans by: 1) broadened basis of PVII with posteroventral projection (lobe) (vs. basis of PVII oval, without posteroventral projection (lobe)); 2) larger coxal gills of PVII with the gill /bases pereopod ratio about $0.76 / 1$ (vs. $0.42 / 1$ in $S$. ambulans); 3) peduncle of UIII with 2 spines (vs. peduncle trapezoidal, with 1 weak spine in S. ambulans); 4) 7-segmented flagellum of AII (vs. 5 -segmented in S. ambulans); 5) inner plate of MxII with oblique row of 8 short plumose setae (vs. inner plate of MxII with oblique row of 6 short plumose setae in S. ambulans).

For the differences from Synurella spiridonovi Marin et Palatov sp.n. see below.

DISTRIBUTION AND ECOLOGY. The species is presently known only from the Ispani peat bog $\left(41^{\circ} 51^{\prime} 41.63^{\prime \prime} \mathrm{N}\right.$ $\left.41^{\circ} 47^{\prime} 8.94^{\prime \prime} \mathrm{E}\right)$, the Kobuleti Nature Reserve, Kobuleti, Republic of Ajaria (Adjara), Georgia.

\section{Synurella spiridonovi Marin et Palatov sp.n. Figs 1, 16-18.}

MATERIAL EXAMINED. Holotype, + (bl. $7.5 \mathrm{~mm}$ ), ZMMU Mb-1216, Georgia, Samegrelo-Zemo Svaneti, Khobi Municipality, small pond near road Chaladidi-Kulevi-Poti, $42^{\circ} 11^{\prime} 42.0^{\prime \prime} \mathrm{N} 41^{\circ} 42^{\prime}$ 


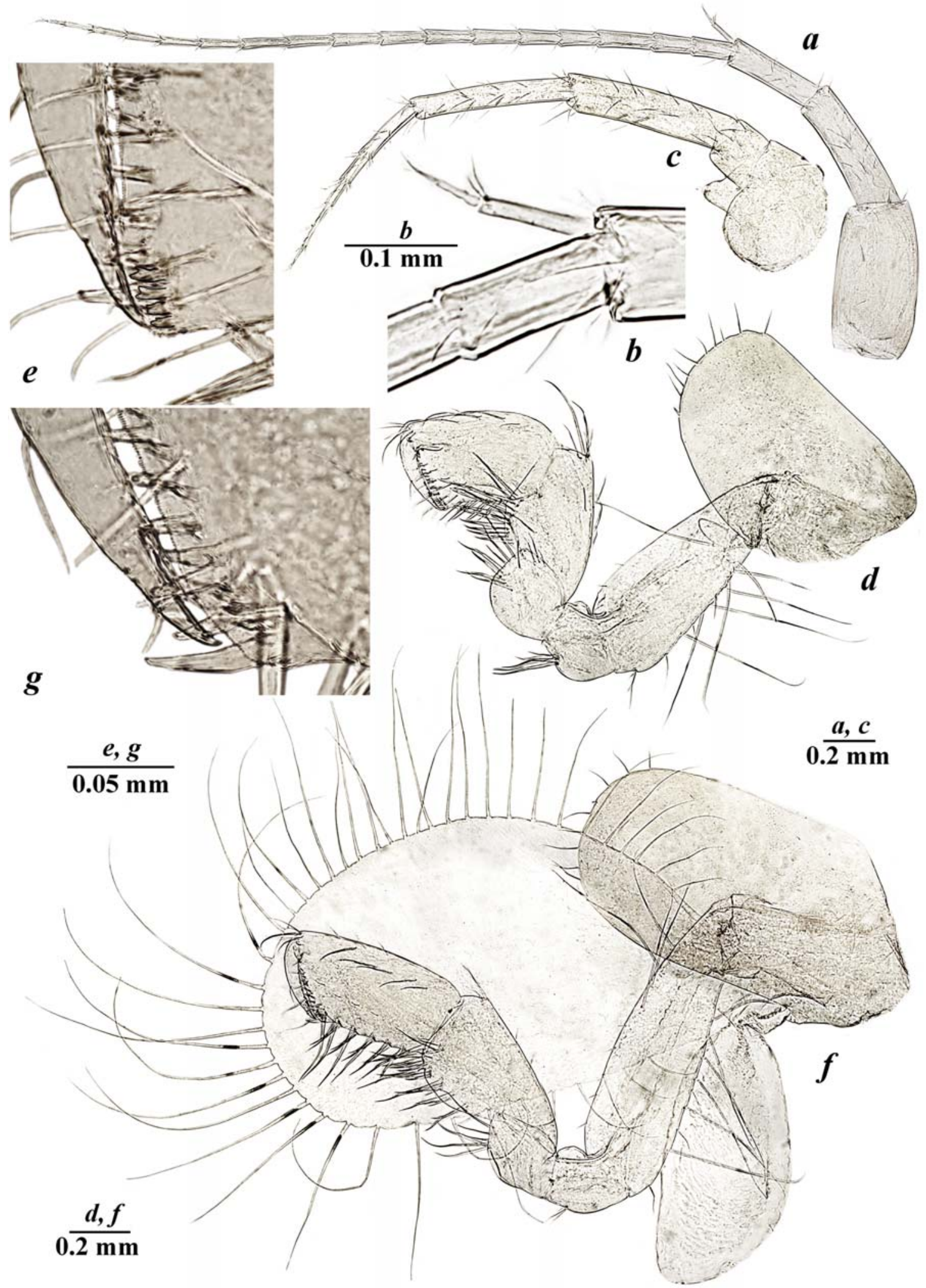

Fig. 16. Synurella spiridonovi Marin et Palatov sp.n., o: $a$ - antenna I; $b$ - accessory flagellum of antenna I; $c-$ antenna II; $d-$ gnathopod I; $e$ - distoventral palmar margin of chela of GnI; $f$ - gnathopod II; $g$ - distoventral palmar margin of chela of GnII.

Рис. 16. Synurella spiridonovi Marin et Palatov sp.n., $+: a$ - антенна I; $b$ - добавочный жгутик антенны I; $c$ - антенна II; $d-$ гнатопода I; $e$ - дистовентральный край ладони клешни $\mathrm{GnI} ; f$ - гнатопода II; $g$ - дистовентральный край ладони клешни GnII. 

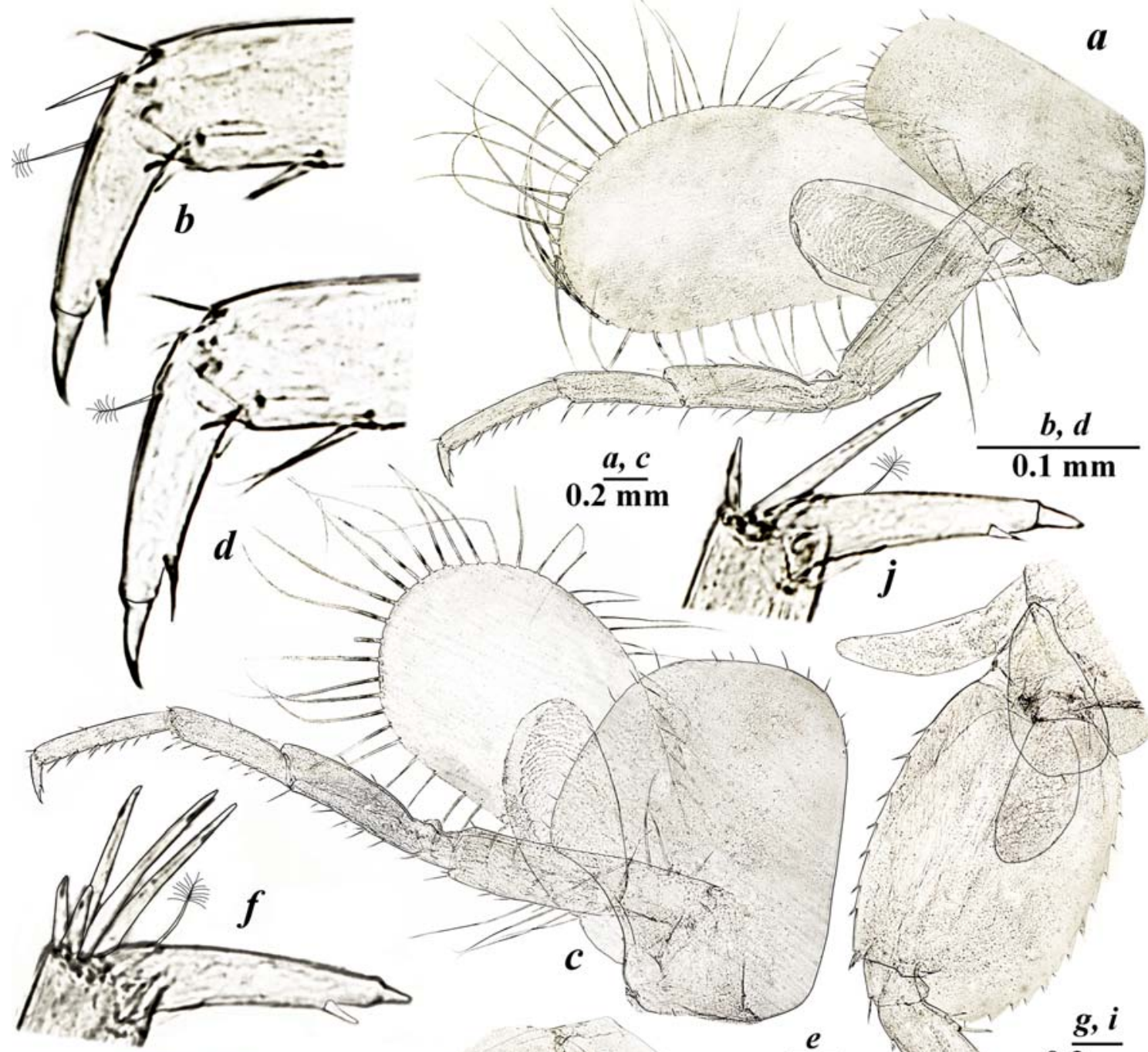

$\boldsymbol{a}$

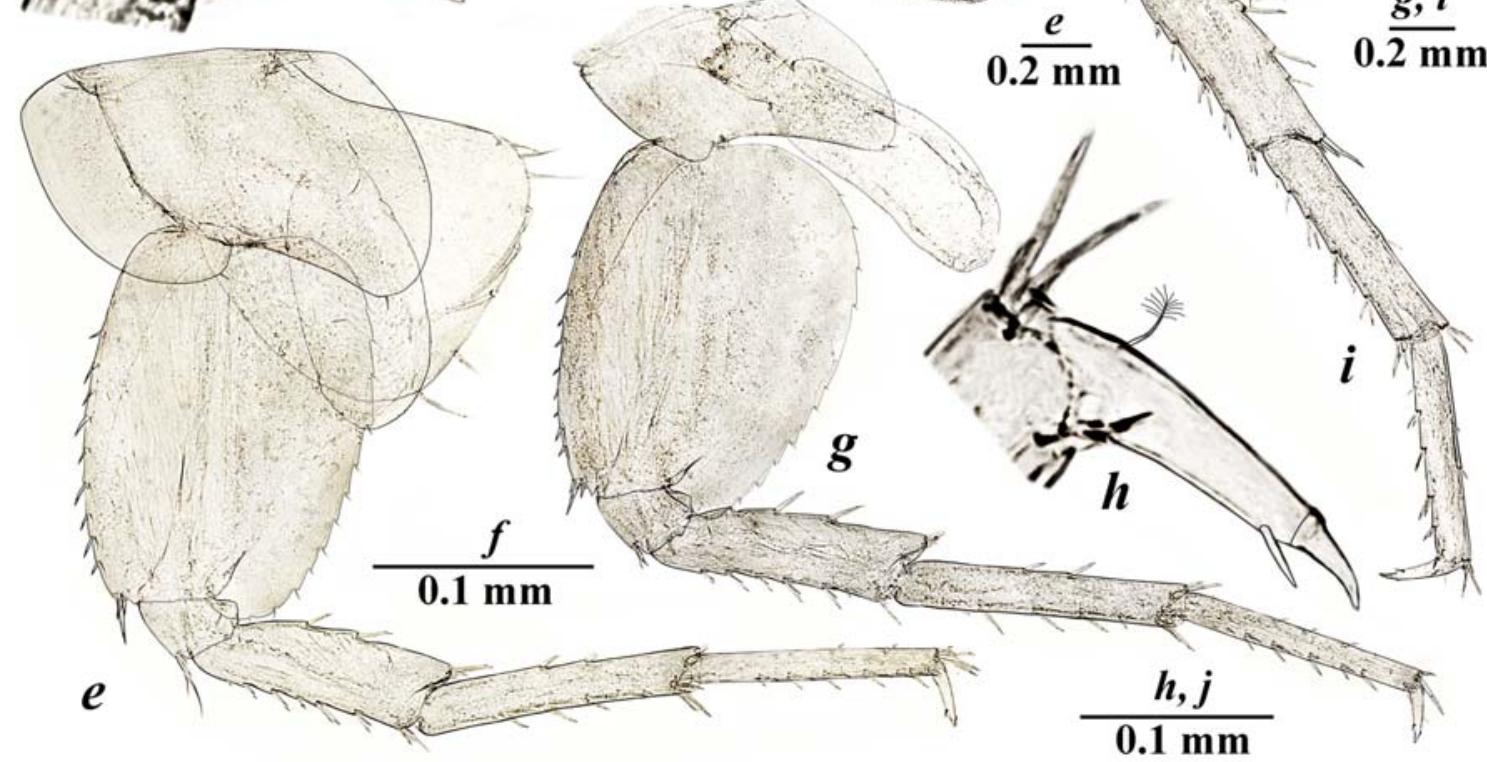

Fig. 17. Synurella spiridonovi Marin et Palatov sp.n., $q: a-$ pereopod III; $b$ - dactylus of PIII; $c$ - pereopod IV; $d$ - dactylus of PIV; $e$ - pereopod V; $f$ - dactylus of PV; $g$ - pereopod VI; $h$ - dactylus of PVI; $i$ - pereopod VII; $j$ - dactylus of PVII.

Рис. 17. Synurella spiridonovi Marin et Palatov sp.n., $+: a$ - переопода III; $b$ - дактилус PIII; $c$ — переопода IV; $d$ - дактилус $\mathrm{PIV} ; e$ - переопода V; $f$ - дактилус PV; $g$ - переопода VI; $h$ — дактилус PVI; $i$ - переопода VII; $j$ - дактилус PVII. 

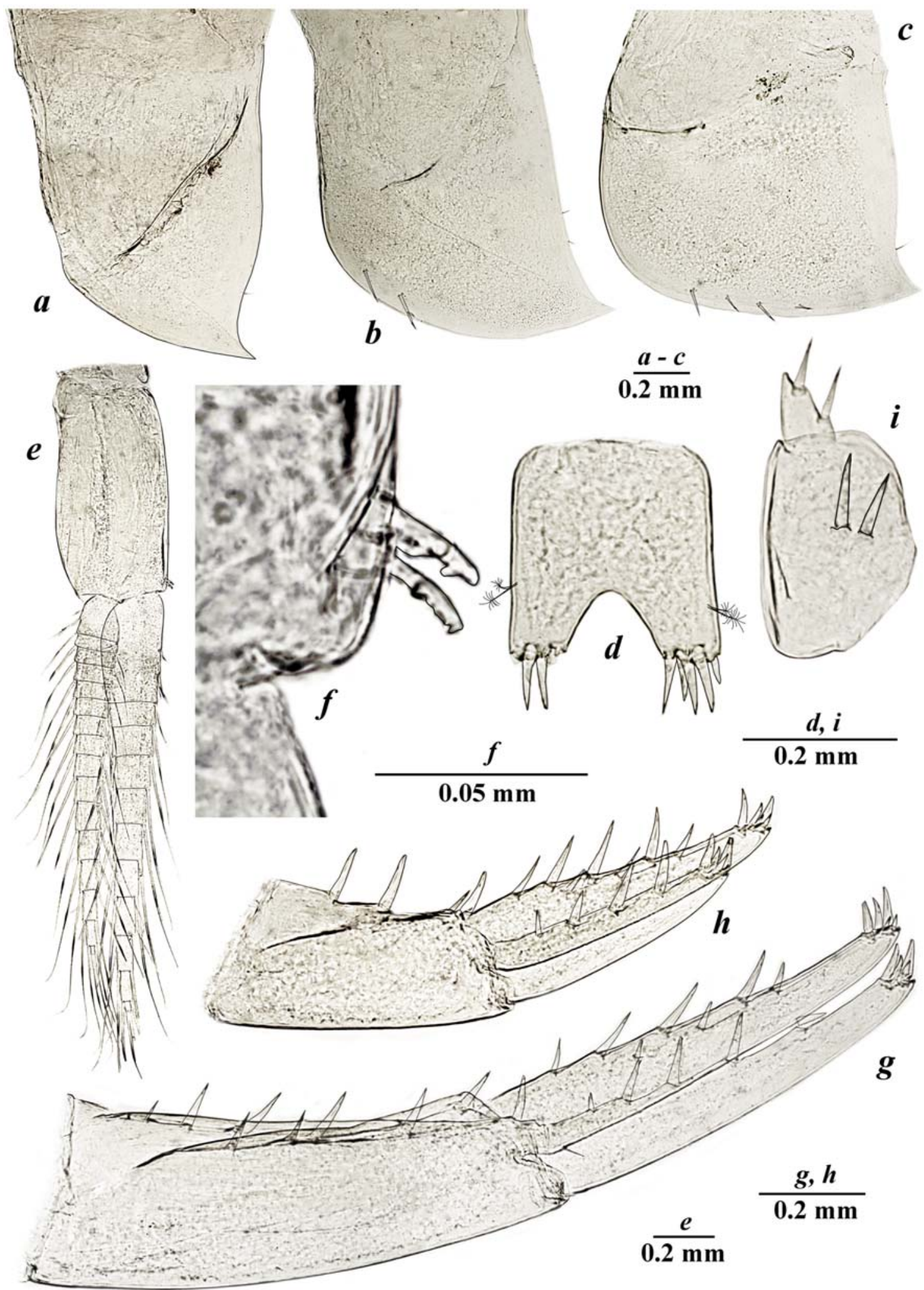

g

Fig. 18. Synurella spiridonovi Marin et Palatov sp.n.,, : $a$ - epimeral plate I; $b$ - epimeral plate II; $c$ - epimeral plate III; $d$ - telson; $e$ - pleopod II; $f$ - hooks of retinacula of pleopod II; $g$ - uropod I; $h$ - uropod II; $i$ - uropod III.

Рис. 18. Synurella spiridonovi Marin et Palatov sp.n.,,$: a-$ эпимеральная пластинка I; $b-$ эпимеральная пластинка II; $c-$ эпимеральная пластинка III; $d$ - тельсон; $e$ - плеопода II; $f$ - крючки ретинакулы плеоподы II; $g$ - уропода I; $h$ - уропода II; $i$ - уропода III. 
19.9"E, about 2 meters above sea level, hand net sampling, 29.01. 2019, coll. I. Marin, V. Maslova. Paratype. 1 ( (bl.7.2 mm), ZMMU Mb-1217, same locality and data as holotype.

ADDITIONAL MATERIAL. 2 옹, same locality and data as holotype.

ETYMOLOGY. The species is named after Dr. Vassily Albertovich Spiridonov (7.04.1957-17.12.2020), the famous Russian carcinologist, who has studied the marine fauna and communities of the Black Sea for many years.

DESCRIPTION. Body (Fig. 1): moderately stout; the largest collected + has bl. $7.5 \mathrm{~mm}$.

Antenna I (Fig. 16a) about 50\% of body length, about $1.9 \mathrm{X}$ longer than antenna II; primary flagellum with 17 segments, with aesthetascs on distal segments; accessory flagellum 2-segmented, distal segment about 2.0X shorter than basal one (Fig. 16b).

Antenna II (Fig. 16c): gland clone distinct, distally pointed; peduncle about 1.7-2.0X longer than flagellum, with robust setae tightly covering segments 3 and 4 , peduncle of segment 4 about 1.1X longer than segment 5; flagellum 6segmented, without calceoli.

Mandible: left mandible incisor 5-dentate, lacinia mobilis 5-dentate, with 3 robust plumose accessory setae; molar process with 1 seta. Right mandible incisor 4-dentate, lacinia mobilis toothed, triturative, lobes with numerous protuberances; underlying with a row of 3 robust plumose setae; molar process similar to left mandible. Palp 3-segmented, segment 2 with 7-8 setae; segment 3 about $3.0 \mathrm{X}$ longer than wide, with convex margins, with 8-10 separate D-setae, 2 C-setae, 1 B-seta and 4 separate E-setae.

Labrum (upper lip): oval, apical margin with numerous small fine setae.

Labium (lower lip): inner lobes feebly developed.

Maxilla I: inner plate with 8 plumose marginal setae, outer plate with 7 apical comb-spines; palp 2-segmented, distal segment pubescent, about $2.5 \mathrm{X}$ of basal segment, apical margin of distal segment with 6 bifurcated and 4 simple setae.

Maxilla II: inner, outer plates covered in pubescent setae; inner and outer plates subequal in length, weakly narrowing distally, with 13 apical setae; inner plate narrowing slightly distally, with group of dense short setae on apex, with oblique row of 8 short plumose setae.

Maxilliped: inner plate much shorter than outer plate, with 2 spines, 1 robust plumose and 1 simple seta apically, and 6 robust plumose setae laterally; outer plate narrow, with a double row of 26 medial stiff simple setae of different length; palp quadriarticulate, article I without setae on outer margin, article II with a row of 24 simple setae on inner margin and 2 setae on outer margin, article III sub-quadrate; dactylus with 1 seta on outer margin and with 4 thin setae at inner margin, nail long, slender, with 1 thin seta at hinge.

Gnathopod I (Fig. 16d): smaller than gnathopod II; coxal plate sub-rectangular, distally rounded, with 10 apical and numerous facial setae, width/depth ratios is $0.66-0.67$; basis width/length ratio is $0.43 / 1$, with $1-2$ short setae on anterior margin, 10 long setae on inner face and 2 long setae on posterior margin; merus with 12 distal setae; carpus is $0.58 \mathrm{X}$ of basis and $0.85 \mathrm{X}$ of propodus, with $13-15$ serrated setae in inner margin and 4 simple setae in outer margin; propodus $1.7 \mathrm{X}$ longer than broad, with 6 simple setae in anterior margin and 8 serrated setae in posterior margin; distal margin of palm almost straight, slightly oblique, with double row of 6 inner and 6 outer bifurcate robust setae; palmar groove (depression) (Fig. 16e) feebly developed, with 5 inner and 5 outer robust setae; dactylus with 1 outer seta.
Gnathopod II (Fig.16f): coxal plate sub-rectangular, with 10 apical and numerous facial setae, width/depth ratios is 0.56 ; basis width/length ratio is $0.32 / 1$, with several (5-7) long setae inserted along posterior margin and with 4 long simple setae and 4 short setae in anterior margin; ischium with 3 short simple setae; merus with 6 distal setae; carpus is $0.5 \mathrm{X}$ of length of basis and $0.54 \mathrm{X}$ of propodus, with 3-4 anterior simple setae and 4 groups of plumose posterior setae; propodus $2.0 \mathrm{X}$ longer than broad, with 3 simple anterior setae, 5 superior medial, 4-5 inferior medial and 5 groups of posterior setae; palm oblique with a double row of 6 inner and 6 outer bifurcate robust setae; palm groove (depression) (Fig. 16g) feebly developed, with 4 inner and 4 outer robust setae; dactylus without inner and with 1 outer seta.

Pereopod III (Fig. 17a): coxal plate sub-rectangular, with 8 apical and numerous facial setae, width/depth ratio is 0.54 ; basis about $4.4 \mathrm{X}$ as long as wide, with long anterior and posterior simple setae; merus about $0.58 \mathrm{X}$ of basis, about $1.2 \mathrm{X}$ of carpus and propodus in length; carpus about $0.95 \mathrm{X}$ of propodus in length; dactylus (Fig. 17b) about $0.34 \mathrm{X}$ of propodus, with plumose seta on outer margin and 1 additional spine accompanying with seta along ventral margin.

Pereopod IV (Fig. 17c): subequal to PIII in length; coxal plate expanded and broadly convex distally, posterior margin with shallow excavation, distal margin with 18 apical short setae and numerous facial setae, width/depth ratio is $1.28 / 1$; basis about $4.5 \mathrm{X}$ as long as wide, with long anterior and posterior simple setae; merus about $0.45 \mathrm{X}$ of basis, about $1.18 \mathrm{X}$ of carpus and about $1.15 \mathrm{X}$ of propodus in length; carpus subequal of propodus in length; dactylus (Fig. 17d) about $0.36 \mathrm{X}$ of propodus, with 1 plumose seta on outer margin and 1 additional spine accompanying with seta along ventral margin.

Pereopods V, VI, VII with the length ratio $1 / 1.15 / 0.97$.

Pereopod V (Fig. 17e): coxal plate large, bilobate with distinct anterior and posterior lobes; posterior and anterior lobes with 1 margin simple seta each, with numerous facial setae; basis about $1.36 \mathrm{X}$ as long as wide, with numerous facial setae, posterior margin slightly convex, armed with 14 shallow serrations, with distal corner, anterior margin with 9 split-tipped robust and 4 distal setae; merus about $0.62 \mathrm{X}$ of basis, $0.82 \mathrm{X}$ of carpus and subequal of propodus in length; dactylus (Fig. 17f) approximately $0.34 \mathrm{X}$ of propodus, with 1 plumose seta on outer margin and 1 additional spine accompanying with seta along ventral margin.

Pereopod VI (Fig. 17g): coxal plate bilobate, with distinct posterior and vestigial anterior lobes; anterior lobe without setae, posterior lobe with 1 margin seta, each with numerous facial setae; basis about $1.31 \mathrm{X}$ as long as wide, with numerous facial setae, posterior margin convex, armed with 14 shallow serrations, anterior margin with 10 splittipped robust and 4 distal setae; merus about $0.69 \mathrm{X}$ of basis, $0.88 \mathrm{X}$ of carpus and subequal of propodus in length; dactylus (Fig. 17h) approximately $0.30 \mathrm{X}$ of propodus, with plumose seta on outer margin and 1 additional spine accompanying with seta along ventral margin.

Pereopod VII (Fig. 17i): coxal plate small, semi-lunar, with 1 posterior seta; basis about $1.36 \mathrm{X}$ as long as wide, with numerous facial setae, posterior margin convex, armed with 14 serrated setae and with distinct distal corner, anterior margin with 7 split-tipped robust and 3 distal setae; merus about $0.60 \mathrm{X}$ of basis, about $0.97 \mathrm{X}$ of carpus and subequal of propodus in length; dactylus (Fig. 17j) approximately $0.35 \mathrm{X}$ of propodus in length, with 1 plumose seta on outer margin and 1 additional spine accompanying with seta along ventral margin. 
Gills, brood plates (Fig. 17): coxal gills on somites IIVII, somites V-VII with lanceolate sternal gill on each. Coxal gills II-VII ovoid, gills/bases pereopod ratios are $0.97 / 1,0.80 / 1,0.81 / 1,0.70 / 1,0.74 / 1$ and $0.49 / 1$, respectively. Brood plates on somites II-V slender, setaceous, decreasing in size posteriorly.

Pleopods (Fig. 18e). Pleopod I peduncle with 2 coupling hooks in retinacula, without lateral setae; outer and inner rami with 13 and 18 segments, respectively; basal segment of outer ramus with 2 clothes-pin setae. Pleopod II peduncle with 2 coupling hooks in retinacula, without setae (Fig. 18f); outer and inner rami with 12 and 17 segments, respectively; basal segment of outer ramus with 2 clothes-pin setae. Pleopod III peduncle with 2 coupling hooks in retinacula, without lateral setae; outer and inner rami with 10 and 14 segments, respectively; basal segment of outer ramus with 2 clothes-pin setae.

Epimera. Epimeron I (Fig. 18a) distally produced and sharped, ventral margin without spines, posterior margin with 1 seta. Epimeron II (Fig. 18b) distally produced and sharped, ventral margin armed with 2 spines, posterior margin with 2 setae. Epimeron III (Fig. 18c) distally produced and sharped, ventral margin armed with 4 spines, posterior margin with 1 seta.

Urosomites completely fused, smooth.

Uropod I (Fig. 18g): peduncle about 3.0X as long as wide, with dorsointernal row of 3 robust spines, 1 subdistal spine and 4 dorsoexternal robust spines; exopodite slightly shorter than endopodite; endopodite not paddle-like, with 4 dorsolateral, 5 apical spines and 1 ventral seta; exopodite with 5 dorsolateral and 5 apical spines.

Uropod II (Fig. 18h): peduncle about $0.81 \mathrm{X}$ of endopodite in length, with 1 outer and 3 inner robust spines; exopodite about $0.8 \mathrm{X}$ of endopodite in length, with 5 outer and 5 apical robust spines; endopodite with 4 outer and 5 apical robust spines.

Uropod III (Fig. 18i): uniramous, peduncle trapezoidal, about $1.4 \mathrm{X}$ as long as wide, with a 2 weak spines and 2 simple setae; lateral and apical margin of ramus armed with 2 weak spines.

Telson (Fig.18d): close to square or trapezoidal, about $1.15 \mathrm{X}$ as long as broad; distal margin with $\mathrm{V}$-shaped distal notch, reaching about $1 / 3$ of its length, each lobe armed with 5 robust spines, with 2 additional submarginal plumose setae.

COLORATION. The body and appendages yellowish or grayish transparent; well-pigmented black eyes well seen.

GENBANK ACCESSION NUMBERS. MZ449252MZ449256.

TAXONOMIC REMARKS. The new species can be clearly separated from Synurella ambulans: 1) basis of PVII with posteroventral projection (lobe) (vs. basis of PVII oval, without posteroventral projection (lobe) in $S$. ambulans); 2) peduncle of UIII with 2 spines (vs. peduncle trapezoidal, with 1 weak spine in $S$. ambulans); 3 ) inner plate of MxII with oblique row of 8 short plumose setae (vs. inner plate of MxII with oblique row of 6 short plumose setae in $S$. ambulans).

Synurella spiridonovi Marin et Palatov sp.n. can be easily separated from Synurella ispani Palatov et Marin sp.n. by: 1) basis of PVII oval, with posteroventral projection (lobe) (vs. basis of PVII broadened distally, with posteroventral projection (lobe) in Synurella ispani Palatov et Marin sp.n.); 2) smaller coxal gill of PVI: ratio of gill/basis pereopod is 0.74/1 (vs. 0.93/1 in Synurella ispani Palatov et
Marin sp.n.); 3) smaller coxal gill of PVII: ratio of gill/basis pereopod is $0.49 / 1$ (vs. 0.76/1 in Synurella ispani Palatov et Marin sp.n.); 4) 6-segmented flagellum of AII (vs. 7-segmented in Synurella ispani Palatov et Marin sp.n.); lanceolate sternal gills of somites V-VII wide and shorter, significantly shorter than basipodite of the corresponding pereopod (vs. narrow and long, longer than basipodite in Synurella ispani Palatov et Marin sp.n.).

DISTRIBUTION AND ECOLOGY. The species is presently known as strictly endemic, living in a small pond near road Chaladidi-Kulevi-Poti $\left(42^{\circ} 11^{\prime} 42.0^{\prime \prime} \mathrm{N} 41^{\circ} 42^{\prime} 19.9^{\prime \prime} \mathrm{E}\right)$, Khobi Municipality, Samegrelo-Zemo Svaneti, Georgia.

\section{Discussion}

The genus Pontonyx Palatov et Marin, 2021 was recently proposed for two species from the former "Synurella derzhavini" species group [Sidorov, Kovtun, 2015]), namely Synurella odessana Sidorov et Kovtun, 2015, described from subterranean water resources in catacombs under Odessa, Ukraine, at northwestern coast of the Black Sea (46 $28^{\prime} 54.0^{\prime \prime} \mathrm{N} 30^{\circ} 42^{\prime}$ $15.2^{\prime \prime}$ ) [Sidorov, Kovtun, 2015], and Synurella ocellai Ruffo, 1972, described from Tirebolu District near Giresun, and presently known also from Ordu Trabzon Provinces along the Black Sea coastline of Turkey [Ruffo, 1972; Özbek, 2018; Marin, Palatov, 2021a]. Moreover, presented new data clearly supported the validity of the genus Pontonyx as well as its well separated phylogenetic clade and Black Sea (Pontius) area distribution. Marin \& Palatov [2021] presented several phylogenetic scenarios (trees) of its relationships within the family Crangonyctidae, but the present study using more sequences of the new species supported it close relationship with the Palaearctic genus Diasynurella Behning, 1940 within the "Stygobromus" clade (see Fig. 1). Copilaş-Ciocianu et al. [2019] estimated that the family is originated before the final break-up of Laurasia at the end of the Cretaceous, and the main lineages separated just after its break-up.

Of course, the fact that representatives of two different genera of the family Crangonyctidae live together is also interesting in the new study and is described for the first time. However, in this case, the more interesting fact is that all the captured females belong to one genus (Synurella), while all collected males to another (Pontonyx), which is confirmed by both morphological studies and molecular genetic studies. At the same time, a thorough search for individuals of the opposite sex for each of the species in the Ispani peat bog did not yield any results, and there were only females of Synurella and males of Pontonyx in the samples. In this regard, we believe that many of the previous descriptions require a thorough revision. For example, the records of both males and females of Synurella ocellai presented by Ekinci \& Miro lu [2017] and Özbek [2018] from the north-western Turkey need to be revised in a view of the present study. Synurella philareti from the lower reaches of the Dnieper [Birštein, 1948] could also belongs to the genus Pontonyx (see 
above) and need to be re-examined on freshly collected material.

Also, additional studies and markers require the study of the time of divergence of the main lineages within the family Crangonyctidae, since they differ by about 10 times according to various studies [CopilaşCiocianu et al., 2019; Palatov, Marin, 2020; Marin, Palatov, 2021a, b] and the present study.

Acknowledgements. The study is supported by the Russian Foundation for Basic Research (RFBR) (grant No. 2004-00803_A). The authors are sending their special thanks to Agniya Sokolova and Veronika Maslova for their help during the sampling and Roman A. Rakitov (Paleontological Institute of Russian Academy of Sciences) for his help with obtaining SEM images; to Alexander A. Prokin (I.D. Papanin Institute of Biology of Inland Waters, RAS) and Andrei A. Przhiboro (Zoological Institute of RAS) for providing an opportunity to get acquainted with additional material on crangonyctid amphipods from the Ispani peat bog (Kobuleti, Adjara, Georgia).

\section{References}

Avise J.C. 1993. Perspective: The evolutionary biology of aging, sexual reproduction, and DNA repair // Evolution. Vol.47. No.5. P.1293-1301. https://doi.org/10.1111/j.1558-5646.1993. tb02155.x

Birštein Y.A. 1948. [The extent and distribution of the genus Synurella (Crustacea, Amphipoda)] // Doklady Akademii Nauk SSSR. Novaja Seriya. Vol.60. No.4. P.701-704 [in Russian].

Copilaş-Ciocianu D., Boroş B.V. 2016. Contrasting life history strategies in a phylogenetically diverse community of freshwater amphipods (Crustacea: Malacostraca) // Zoology. Vol.119. No.1. P.21-29. https://doi.org/10.1016/j.zool.2015.11.001

Copilaş-Ciocianu D., Grabowski M., Pârvulescu L., Petrusek A. 2014. Zoogeography of epigean freshwater Amphipoda (Crustacea) in Romania: fragmented distributions and wide altitudinal variability // Zootaxa. Vol.3893. No.2. P.243-260. http:// doi.org/10.11646/zootaxa.3893.2.5

Copilaş-Ciocianu D., Petrusek A. 2015. The southwestern Carpathians as an ancient centre of diversity of freshwater gammarid amphipods: insights from the Gammarus fossarum species complex // Molecular Ecology. Vol.24. No.15. P.3980 3992. https://doi.org/10.1111/mec.13286

Copilaş-Ciocianu D., Sidorov D.A., Gontcharov A. 2019. Adrift across tectonic plates: molecular phylogenetics supports the ancient Laurasian origin of old limnic crangonyctid amphi- pods // Organisms Diversity \& Evolution. Vol.19. P.191-207. https://doi.org/10.1007/s13127-019-00401-7

Ekinci M., Miro lu A. 2017. Redescription of Synurella osellai Ruffo, 1974 (Crustacea, Amphipoda) from Ordu Province (Turkey) with Some Taxonomic Notes // Turkish Journal of Fisheries and Aquatic Sciences. Vol.17. P.1381-1385. http://doi.org/ 10.4194/1303-2712-v17 631

Folmer O., Black M., Hoeh W. ., Lutz R., Vrijenhoek R. 1994 DNA primers for amplification of mitochondrial cytochrome c oxidase subunit I from diverse metazoan invertebrates // Molecular Marine Biology and Biotechnology. Vol.3. P.294-299.

Guy-Haim T., Simon-Blecher N., Frumkin A., Naaman I., Achituv Y. 2018. Multiple transgressions and slow evolution shape the phylogeographic pattern of the blind cave-dwelling shrimp Typhlocaris // PeerJ. Vol.6. e5268. https://doi.org/10.7717/ peerj.5268

Kimura M. 1980. A simple method for estimating evolutionary rates of base substitutions through comparative studies of nucleotide sequences // Journal of Molecular Evolution. Vol.16. No.2. P.111-120. https://doi.org/10.1007/BF01731581

Koenemann S. 2000. Comparative Systematics of Subterranean Amphipod Crustaceans in the Families Crangonyctidae and Bogidiellidae. Doctor of Philosophy (PhD) dissertation. Biological Sciences, Old Dominion University. https://doi.org/ 10.25777/bjvjvj04

Lefébure T., Douady C.J., Gouy M., Trontelj P., Briolay J., Gibert J. 2006. Phylogeography of a subterranean amphipod reveals cryptic diversity and dynamic evolution in extreme environments // Molecular Ecology. Vol.15. P.1797-1806. http:// doi.org/10.1111/j.1365-294X.2006.02888.x

Marin I.N., Palatov D.M. 2021a. Volgonyx gen.n. and Pontonyx gen.n., two new genera of the family Crangonyctidae (Crustacea: Amphipoda) from the southeastern Europe // Arthropoda Selecta. Vol.30. No.1. P.43-61. http://doi.org/10.15298/arthsel.30.1.05

Marin I.N., Palatov D.M. 2021b. The hidden diversity of the genus Lyurella Derzhavin, 1939 (Crustacea: Amphipoda: Crangonyctidae): four new species from the subterranean habitats of the northwestern Caucasus, Russia // Zootaxa. Vol.5006. No.1. P.127-168. https://doi.org/10.11646/zootaxa.5006.1.17

Özbek M. 2018. An Overview on the Distribution of Synurella Wrześniowski, 1877 genus in Turkey (Amphipoda) // Ege Journal of Fisheries and Aquatic Sciences. Vol.35. No.2. P.111114. http://doi.org/10.12714/egejfas.2018.35.2.01

Palatov D.M., Chertoprud M.V. 2020. Macrozoobenthos communities of springs and streams of the Eastern Circum-Pontic region // Inland Water Biology. Vol.13. No.4. P.583-596. https://doi.org/10.1134/S1995082920040070

Palatov D.M., Marin I.N. 2020. A new genus of the family Crangonyctidae (Crustacea, Amphipoda) from the Palaearctic, with descriptions of two new species from the foothills of the Altai mountains // Zoologichesky Zhurnal. Vol.99. No.10. P.11601186. https://doi.org/10.31857/S004451342010013X

Responsible editor K.G. Mikhailov 